\title{
Métodos de trabalho na anatomia e histologia entomológica
}

de

\author{
Rudolf Barth \\ I. Introdução \\ II. Prescrição da preparação \\ III. Fixação \\ IV. Desidratação \\ $\mathrm{V}$. Inclusão \\ VI. Cortes \\ VII. Coloração \\ VIII. Temas especiais \\ IX. Literatura \\ $\mathrm{X}$. Indice \\ $\mathrm{XI}$. Apêndice
}

\section{I.Introdução.}

No estudo de insetos surgem freqüentemente dificuldades durante os trabalhos morfológicos e principalmente histológicos e microanatômicos. Empregam-se métodos que de maneira nenhuma são indicados para insetos porque foram aprovados no homem, outros vertebrados e avertebrados não podendo ser aplicados no organismo totalmente diferente dos insetos. Como nota-se cada vez mais a falta de um resumo sôbre os métodos de trabalho na histologia e microanatomia entomológica pelos especialistas interessados, tentamos pela presente de apresentar uma publicação com esta finalidade.

As particularidades mais interessantes dos insetos que diferem-nos na comparação dos outros grupos do reino animal são: a) a cutícula quitinosa que inclui sem interrupção o organismo inteiro e a qual é freqüentemente reforçada e endurecida por incrustações, b) a falta de um sistema circulatório completo, c) a ausência de uma ligítima cavidade abdominal, d) a falta de tecido conjuntivo no sentido mais amplo pelo que a localisação dos órgãos não está fixada na cavidade aqui chamada mixoceloma (esta deficiência é compensada em parte funcionalmente pelas traquéias), e) a reação histoquímica dos tecidos freqüentemente diferente, f) a presença de órgãos que faltam nos ou- 
tros grupos e que freqüentemente são tão minúsculos que um estudo isolado encontra as maiores dificuldades.

Os métodos descritos em seguida são experiências do laboratório que foram aprovados sistemàticamente e aplicados com resultados satisfatórios nos laboratórios do Instituto Zoológico da Universidade de Bonn (Alemanha) e do Instituto Oswaldo Cruz no Rio de Janeiro (Brasil). No correr do tempo as diferentes manipulações foram limitadas no seu tempo de duração que os valores indicados representem sempre o mínimo. No emprego destes métodos deve-se proceder com a maior exatidão observando fielmente as prescrições. E de máxima importância de utilisar-se de substâncias puríssimas, controlar as combinações como também observar constantemente as diversas manipulações como fixação, deshidratação e coloração. Trata-se em parte de métodos novos, em parte de modificações de antigos métodos ou de outros que são empregados em grupos de outros animais e mostravam-se aproveitáveis com certas modificações também para insetos.

Os diversos métodos, prescrições e indicações são resumidos em diversos grupos, mesmo obedecendo a uma enumeração contínua podendo assim esta ser aumentada mais tarde se isto for necessário. Desta maneira uma boa orientação em forma de índice é conseguida como RoMeis empregou a na sua excelente obra sôbre a microscopia técnica.

\section{Prescrições da preparação.}

1. Quando trata-se de material para coleções ou de investigações das partes quitinosas no sentido mais amplo bastam para sacrificar os insetos os gáses de éter, clorofórmio, ciancali, eventualmente benzol entre outros. Estes meios causam uma contração dos músculos que pode ser prejudicial nos insetos membranosos (larvas, apterigotas etc.) .

2. Como estes meios (principalmente o clorofórmio) provocam uma deshidratação forte nas membranas intersegmentais, os insetos tornam-se frágeis o que dificulta a sua montagem. Neste caso é preferível de empregar éter acético, pois estas desvantagens diminuem assim devido do ácido acético livre.

3. Nos trabalhos histológicos torna-se freqüentemente necessário um descanso da musculatura para conseguir as medidas e estruturas naturais. A atonia desejada pode ser conseguida antes da fixação com uma lavagem do inseto com extrato de "kava-kava" no que deve-se observar que o líquido injetado sai normalmente se não podem surgir dilatações devido a pressão aumentada:

a) narcose do inseto com éter ou outros meios,

b) injetar imediatamente o extrato de "kava-kava" cuja ação deve ser de 10 a 15 minutos,

c) injetar em seguida o fixador,

d) prosseguimento segundo os métodos de fixação abaixo descritos. 
Solução: 1. Extrato de kava-kava": Misturar $125 \mathrm{~cm}^{3}$ soluto isotônico de $80^{\circ}$ com $7,5 \mathrm{~g}$ de pó de "kava-kava". Depois de resfriar até $37^{\circ}$ adicionar uma pequena porção de diastase (dissolvido no mesmo soluto). Deixar permanecer 2,5 horas a $37^{\circ}$ e filtrar. O extrato não poderá ser conservado por muito tempo. 2. Soluto isotônico: $7,5 \mathrm{~g}$ $\mathrm{NaCl}, 0,42 \mathrm{~g} \mathrm{KCl}, 0,21 \mathrm{~g} \mathrm{CaCl}_{2} 1000 \mathrm{~cm}^{3} \mathrm{H}_{2} \mathrm{O}$ (dist.). $\mathrm{O} \mathrm{CaCl}_{2}$ deverá ser adicionado sòmente depois da dissolução dos outros sais para evitar a formação de carbonato de cálcio insolúvel. O soluto não poderá ser conservado durante muito tempo.

4. No caso se for impossível a lavagem do inseto, poderá o mesmo, narcotisado e aberto, ser colocado durante 15 minutos num extrato de "kava-kava".

5. No caso que não for empregado o extrato de "kava-kava" o inseto sacrificado com éter, clorofórmio etc. deve descançar um pouco antes da fixação (10 minutos os insetos menores e 20 minutos os maiores) até diminuir a contração inicial. Será fácil de dobrar as extremidades. Em seguida fixação.

6. Exame da superfície. Um exame direto com binocular ou "ultropak" ou com luz transparente é muitas vêzes impraticável por causa do brilho ou da coloração etc. Neste caso o preparo de réplicas é necessário. Aplica-se na superfície cuidadosamente limpa uma camada fina de um soluto de celulose, de colofónio ou colódio. 5 a $10 \mathrm{mi}$ nutos após esta camada secou ela pode ser deslocada fàcilmente. Esta réplica representa uma reprodução fiel da superfície que pode ser analisada no microscópio. Esta reprodução torna-se mais plástica quando projetamos em seguida em alto vácuo e com ângulo bem agudo vapores metálicos (shadow-casting).

Solução: Dissolve-se celulose no meio como clorofórmio, éter ou acetona diluindo a depois tanto que poderá atingir todas as cavidades e sulcos. A celulose deve ser absolutamente limpa e o meio de solução não poderá conter restos de água senão a réplica apresenta-se turva.

7. Deslocação de escamas e cerdas. No caso que a superfície das partes quitinosas estiver cheia de escamas, um deslocamento com pincel ou pinca destrói freqüentemente estruturas finas. Neste caso aplica-se um soluto viscoso de celulose. Uma vez sêco o negativo é retirado cuidadosamente deslocando-se assim as escamas e cerdas (eventualmente uma segunda aplicação). Desta forma pode-se tirar as escamas totalmente das asas de lepidópteros delicadas e finas. Recomenda-se de empregar acetona devido a sua rápida evaporação separando e enrolando-se 5 a 15 minutos depois por si os negativos. Nas asas, principalmente nas margens, deve-se tratar subsequientemente apenas pequenas partes para evitar destruições. 
Solução: Preparo da solução de celulose como sob n. ${ }^{\circ} 6$.

8. Formas dos excrementos dos insetos. Para a demonstração das formas pelas dobras rectais são as mesmas, para obter preparações permanentes, tratadas como segue:

a) secadas no banho maria ou na estufa,

b) colocadas em benzol durante 30 minutos a 2 horas de acôrdo com o tamanho,

c) transferidas para acetona durante 20 a 40 minutos,

d) deitadas durante um dia numa solução, bem líquida de celulose (com uma consistência de glicerina),

e) secadas numa placa de vidro. Deve-se prestar atenção que não encontram-se gotas da solução de celulose em baixo do preparado. No caso que a solução foi densa demais de forma que ela passa sôbre a parte externa, devem as formas ser lavadas ràpidamente com acetona pura antes de secar.

Solução: Preparação da solução de celulose como sob n. ${ }^{\circ} 6$.

9. Coloração dos anexos. No exame de escamas, cerdas e outros anexos é freqüentemente indicada uma coloração quando é impossível entrar insuficientemente na estrutura mais fina com outros meios óticos (luz polarisada, microscópio contraste de fase). Neste caso prepara-se a coloração dos anexos in sito junto com a sua base.

10. Com o objeto in vivo o mesmo deve ser deshidratado até o álcool de $96 \%$.

a) desengordurar mergulhando o várias vêzes em éter,

b) álcool de $40 \%$ durante 20 minutos,

c) álcool de $70 \%$ durante 20 minutos,

d) álcool de $96 \%$ durante 20 minutos,

e) soluto de vermelho de congo durante 24 horas,

f) álcool de $96 \%$ (diferenciar),

g) álcool de $100 \%$ durante 1 hora (duas vêzes),

h) xilol durante uma hora (duas vêzes),

i) secar ao ar (para apressar na estufa com $58^{\circ}$ ),

k) deslocamento dos anexos e montagem no ar sêco sob a lamínula, mantida se fôr necessário por fios de vidro. Depois da observação no estado sêco pode ser incluído em bálsamo de canada,

1) passar éter entre lâmina e e lamínula para exclusão de ar,

m) passagem com xilol até substituir o éter por xilol,

n) passagem com bálsamo bem líquido, que eventualmente depois, após da evaporação do xilol, poderá ser substituído. 
Solução: Uma g de vermelho de congo dissolve-se em $100 \mathrm{~cm}^{3}$ de álcool de $96 \%$ sacudindo repetidamente, filtração 24 horas depois. O soluto é estável. Se a concentração aumentar devido a evaporação do álcool deverá ser reposta a quantidade anterior com álcool de $96 \%$.

11. Quando o objeto é sêco pelo ar, deverá ser deitado em álcool:

a) éter para a expulsão do ar,

b) álcool ou benzol durante 5 minutos,

c) álcool de $100 \%$ durante 10 minutos,

d) álcool de $96 \%$ durante 10 minutos,

e) prosseguir como acima sob n. ${ }^{\circ} 10 \mathrm{e}$.

12. No caso que é desejado de incluir o objeto logo em bálsamo de canada os anexos devem ser separados em xilol e colocados em bálsamo de canada.

13. Preparações inteiras de pequenos insetos. Inclusão de objetos não deshidratados: meio de inclusão é glicerina pura $(n=1,456)$. O objeto deverá ser desengordurado antes com éter.

a) colocar em $\mathrm{H}_{2} \mathrm{O}$ (dist.),

b) retirada da água com papel de filtro,

c) deitar uma gota de glicerina evitando a formação de bolas de ar. Deve-se observar que o inseto deverá ficar no éter antes de deitá-lo em $\mathrm{H}_{.} 0$ até que o ar tenha saído das traquéias.

d) colocação da lamínula que deverá ser suficientemente apoiada nos seus lados por pequenas colunas de cêra ou melhor ainda por fios ou cacos de vidro dando assim uma posição horizontal. Glicerina é higroscópico. Quando tratar-se de preparação permanente a lamínula deverá ser fechada posteriormente nas suas extremidades (veja n. ${ }^{\circ} 17$ e 18).

14. Para evitar irregularidades na passagem para glicerina, passa-se insetos delgados (larvas, apterigotas etc.) Através de mistura de água-glicerina para glicerina pura:

a) $\mathrm{H}_{2} \mathrm{O}$ (distilada),

b) 5 partes de $\mathrm{H}_{2} \mathrm{O}$ e 1 parte de glicerina,

c) 3 partes de $\mathrm{H}_{.} \mathrm{O}$ e 1 parte de glicerina,

d) 1 parte de $\mathrm{H}_{.2} \mathrm{O}$ e 1 parte de glicerina,

e) glicerina pura.

(Duração do tratamento de cada passagem 10 a 30 minutos conforme o tamanho do objeto) .

15. Nos casos de insetos delgados recomenda-se freqüentemente uma anterior coloração total fraca:

a) desengordurar em éter,

b) colocação em $\mathrm{H}_{.0}$ (dist.), 
c) colocação no soluto de coloração: (1.) vermelho neutro $(0,1 \%)$ em $\mathrm{H}_{2} \mathrm{O}$ (dist.) ou (2.) azul de metilena $(0,1 \%)$ em $\mathrm{H}_{2} \mathrm{O}$ (dist.), duração cada vez uma hora.

d) lavagem em $\mathrm{H}_{0} 0$ (dist.),

e) si houve excesso de coloração, a côr pode ser retirada com álcool de $70 \%$,

f) continuação como sob n. ${ }^{\circ} 14$ a.

Pode-se empregar também hemalumen:

a) da água para hemalumen (veja n. ${ }^{\circ} 117$ ) 2 a 3 horas,

b) lavagem em $\mathrm{H}_{2} \mathrm{O}$ (corr.) 30 minutos a 1 hora,

c) excesso de coloração pode ser diminuído por ácido clorídrico $\left(0,1 \%\right.$ em $\left.\mathrm{H}_{2} \mathrm{O}\right)$,

d) neutralisar em bicarbonato de sódio $\left(\mathrm{NaHCO}_{3}\right) \quad\left(5 \%\right.$ em $\left.\mathrm{H}_{2.0}\right)$ 2 a 3 minutos,

e) lavagem em água corrente 30 minutos a 1 hora,

f) continuação como sob n. ${ }^{\circ} 14 a$. No caso se desejar inclusão em bálsamo de canada continuação através da série crescente de álcool (veja n. ${ }^{\circ} 83$ e 86 ).

16. Em vez de glicerina pode-se empregar xarope aborrachada segundo v. Apáthy $(\mathrm{n}=1,524)$ : em $50 \mathrm{~cm}^{3} \mathrm{H}_{2} 0$ (dist.) são dissolvidos $50 \mathrm{~g}$ de goma arábica (pedacinhos) e $50 \mathrm{~g}$ de açúcar de cana no banho maria. Depois adiciona-se $1 \%$ de formol. A massa endurece ràpidamente podendo ser liquidificada por calor.

17. Fechamento: O melhor método para pequenos objetos é o de ZELLER recomendado por ROMEIS:

a) O preparado é colocado numa pequena lamínula e coberto com o meio de inclusão (ou glicerina ou água),

b) vira-se a lamínula colocando a numa segunda mas maior lamínula devendo o espaço entre ambas ser preenchido pelo meio de inclusão não podendo sobrar glicerina nas margens. Se isto acontecer, deve ser retirado com papel de filtro,

c) vira as duas lamínulas ficando a menor por baixo,

d) algumas gotas de bálsamo de canada numa lâmina e espalhar numa área um pouco menor do que a da lâmina maior porém bem maior do que a da lamínula menor,

e) colocação das lamínulas na lâmina, se possível horizontalmente assim que todas as partes tenham contato simultâneamente.

18. Fechamento de objetos maiores, isto é a distância entre lamínula e lâmina é grande: gelatina bicromada de potássio seguindo RUiJTer (1934). Num soluto quente de $38^{\circ}$ com $20 \mathrm{~g}$ de gelatina em $100 \mathrm{~cm}^{3}$ água timolada saturada misturam-se $10 \mathrm{~cm}^{3}$ de um soluto de bicromado de potássio. O soluto endurece no escuro como gêlo. Para o uso liquidifica-se pouco desta massa a $37^{\circ}$ fechando a lamínula com 
isto cuidadosamente com um pincel. Em seguida deixa-se secar em temperatura ambiente em luz (!). Por efeito da luz a massa torna-se indissolúvel.

19. Inclusão e clarificação de pequenos insetos como preparados totais. O inseto morto ou também material sêco é aquecido segundo Costa Lina em hidróxido de potássio $(\mathrm{KOH})$ a $10 \%$ ou em hidróxido de sódio $(\mathrm{NaOH})$ em banho maria. No caso de pequenos insetos, para evitar destruições de membranas intersegmentais finas aquece-se paulatinamente a $80^{\circ}$ (eventualmente pode-se reduzir o hidróxido a $5 \%$ ), em insetos maiores até a fervura. Depois ter sido atingido o grau desejado do amolecimento e clarificação com uma distruição das partes internas não quitinisadas deixa-se refrescar passando através da série de álcool e xilol para o bálsamo de canada.

20. Se desejar uma coloração a quitina pode ser tingida com vermelho de congo (veja sob n. ${ }^{\circ} 10$ ) em álcool de $96 \%$. Como diversas partes quitinosas aceitam mais ràpidamente orange do que vermelho de congo, pode-se conseguir em certos casos uma coloração de contraste com a mistura do vermelho de congo - orarıge GG (veja sob n. ${ }^{\circ} 132$ ) .

21. Maceração de insetos maiores. Recomenda-se de juntar ao hidróxido de potássio usado sob n. ${ }^{\circ} 19$ uma adição de $1 \%$ de hidrato de clorídrico. Se depois de aquecimento a clarificação for insuficiente, pode-se clarificar com perhidrol diluído. Diluição de perhidrol $\left(\mathrm{H}_{2} \mathrm{O}_{2}\right)$ com água até 3 a $10 \%$ conforme o tamanho dos pigmentos. A clarificação pode extender-se sôbre vários dias. Com permanência mais demorada nesta mistura começa o processo macerizante.

22. Branqueamento de pigmentos (veja-se também n. ${ }^{\circ} 19,21$ e 23): Tamanho do objeto $3 \mathrm{~mm}$.

a) colocação no soluto de branqueamento controlando até conseguir o grau desejado,

b) neutralisação em ácido acético de $1 \%, 10$ a 30 minutos,

c) água corrente durante 30 minutos,

d) lavagem em $\mathrm{H}_{\Perp} 0$ (dist.) durante 30 minutos,

e) série de álcool até xilol e bálsamo de canada.

Solução: Líquido de branqueamento: Soluto de perhidrol a $3 \%$ e $\mathrm{KOH}$ a $0,5^{\prime}$ ' em $\mathrm{H} . .0$ (dist.), no caso se desejar coloração posterior emprega-se em vez de $\mathrm{KOH}$ fosfato de sódio a $1 \%\left(\mathrm{Na}_{2} \mathrm{HPO}_{4}\right)$.

23. Branqueamento com diafanol e amolecimento simultâneo da quitina: Como tratamento com diafanol (ácido acético com dióxido de cloro) freqüentemente tem por conseqüência uma destruição mais ou menos forte dos tecidos, recomenda-se o emprêgo de ácido nítrico com dióxido de cloro que trabalha mais brandamente. 
Emprêgo :

a) depois da fixação leva-se o objeto até ao álcool de $96 \%$ e depois para o álcool de $65 \%$,

b) colocação em ácido nítrico com dióxido de cloro no escuro até a decoloração dos pigmentos respectivamente amolecimento da quitina (podendo o processo demorar algumas semanas). No caso se o soluto ficar claro deve ser substituído por um novo,

c) passagem para uma mistura de tiosulfato de sódio a $2,5 \%$ e soluto de nitrato de sódio a $5 \%\left(\mathrm{em} \mathrm{H}_{2} 0\right)$ durante 24 horas (mudar algumas vêzes),

d) lavagem em $\mathrm{H}_{2} \mathrm{O}$ corrente durante 3 horas,

e) série com álcool até xilol.

Solução: preparo do ácido nítrico com dióxido de cloro: pouco antes do uso são misturadas 10 partes de um soluto aquoso de dióxido de cloro com uma parte de ácido nítrico oficinal $(25 \%$, peso específico 1,145 a 1,148 , correspondendo a $18,5^{\circ}$ Bé) .

Dióxido de cloro prepara-se conforme MOLLER:

a) num vidro graduado de $2000 \mathrm{~cm}^{3}$ que pode ser fechado colocam-se $220 \mathrm{~cm}^{3} \mathrm{H}_{2} \mathrm{O}$ (dist.),

b) num vidro graduado de $100 \mathrm{~cm}^{3}$ colocam-se $12 \mathrm{~cm}^{3} \mathrm{H}_{2} 0$ (dist.) juntando devagar e mexendo $44 \mathrm{~cm}^{3}$ de $\mathrm{H}_{2} \mathrm{SO}_{4}$ concentrado,

c) deixar resfriar,

d) juntam-se a b) $12 \mathrm{~g}$ de clorato de potássio $\left(\mathrm{KClO}_{3}\right)$, cuidado explosível!,

e) o pequeno vidro aberto é colocado no grande e todo fechado bem com óleo de parafina e conservado no escuro durante 24 a 36 horas,

f) $0 \mathrm{ClO}_{2}$ que aparece no pequeno vidro foi diluído na água do grande vidro. A côr deste soluto de dióxido de cloro é de côr amarela de ouro forte, conservação num frasco com rolha esmeril no escuro.

24. Clarificação (método de Spalteholz) : Neste método recomenda-se especialmente o emprêgo de baixa pressão.

a) fixação em formol, álcool, Carnoy etc., possìvelmente não em fixadores com ácido ósmico ou sublimados. Uma fixação suficiente é a base de um resultado bom sendo que excesso de fixação nem prejudica. O melhor é o líquido de Carnoy.

b) lavagem em $\mathrm{H}_{2} \mathrm{O}$ (dist.), 
c) branqueamento em $\mathrm{H}_{2} \mathrm{O}_{2}$ de $5 \%$ a $20 \%$ conforme o tamanho dos pigmentos. $\mathrm{O}_{\mathrm{H}_{2}} \mathrm{O}_{2}$ deve ser neutralisado com $\mathrm{LiC}_{3}, \mathrm{NaOH}$ ou $\mathrm{NH}_{3}$. Branquear até a distruição dos pigmentos. Se o resultado for insuficiente pode ser branqueado com diafanol,

d) lavagem, desidratação (com cuidado) até o benzol puro,

e) líquido de clarificação segundo Spalteholz, duração conforme do tamanho das peças. O processo deve ser controlado diàriamente podendo ser apressado numa estufa de $40^{\circ}$ a $45^{\circ}$.

Solução: óleo de Wintergreen (salicilato de metila) e benzoato de benzila na proporção de 4 a 1 . É recomendável uma coloração simultânea fraca e total de pequenos objetos delicados. Para uso adiciona-se ao álcool de $70 \%$ e $1 \mathrm{~cm}^{3}$ de um soluto de $1 \%$ de azul de toluidina por $100 \mathrm{~cm}^{3}$ de álcool. O objeto fica durante 24 horas nêsse soluto. O álcool de $96 \%$ subseqüente é substituído por um soluto de $1 \%$ de vermelho de congo em álcool de $96 \%$.

25. Clarificação. Bons resultados observam-se também quando emprega-se em vez do soluto de clarificação conforme Spalteholz em n. ${ }^{\circ} 24$ e) uma mistura de partes iguais de óleo de anilina, óleo de cravo e terpinol.

26. Líquidos de conservação para manutenção de côres naturais:

Os métodos usuais para a conservação de material para os museos podem ser empregados também em certos sentidos para os insetos. Indicados para lagartas, pupas etc., também para aranhas. Antes de colocar os objetos no líquido de preparação êstes devem ser desengordurados em éter. $O$ ar contido nêstes extrai-se com vantagem pela bomba de jato de água apressando-se e intensivando-se ao mesmo tempo a infiltração. Recomenda-se também na infiltração com o líquido de conservação o emprêgo de baixa pressão.

Método segundo KLotz:

Líquido de preparação:

$\mathrm{Em} 200 \mathrm{~cm}^{3}$ de $\mathrm{H}_{2} \mathrm{O}$ (dist.):

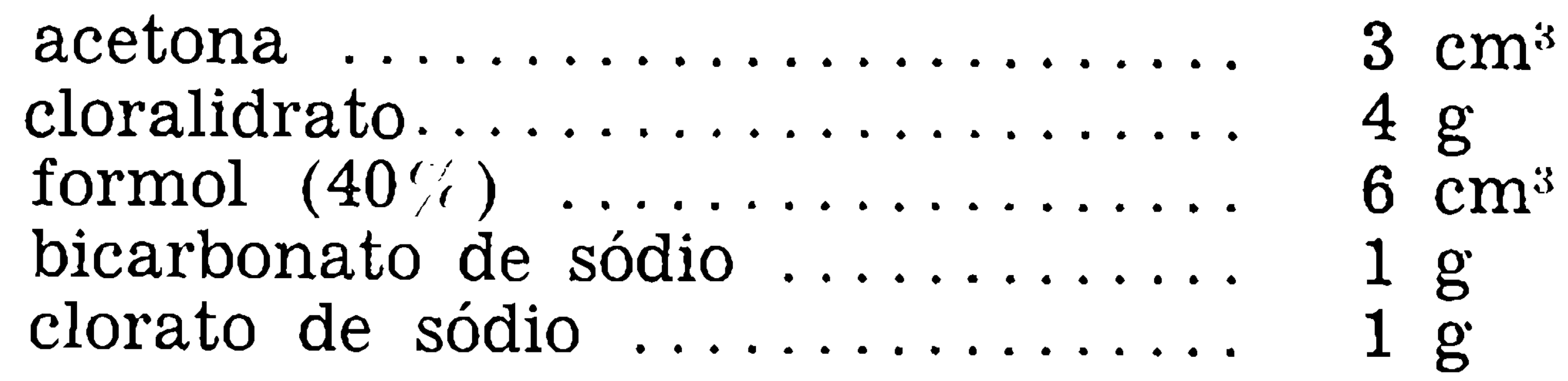

Nêste líquido objetos menores ficam 10 dias, maiores 15 dias. O líquido não deve ser menos do que 20 vêzes o volume dos objetos. Líquido de conservação:

em $200 \mathrm{~cm}^{3} \mathrm{H}_{\mathrm{O}} \mathrm{O}$ (dist.) :

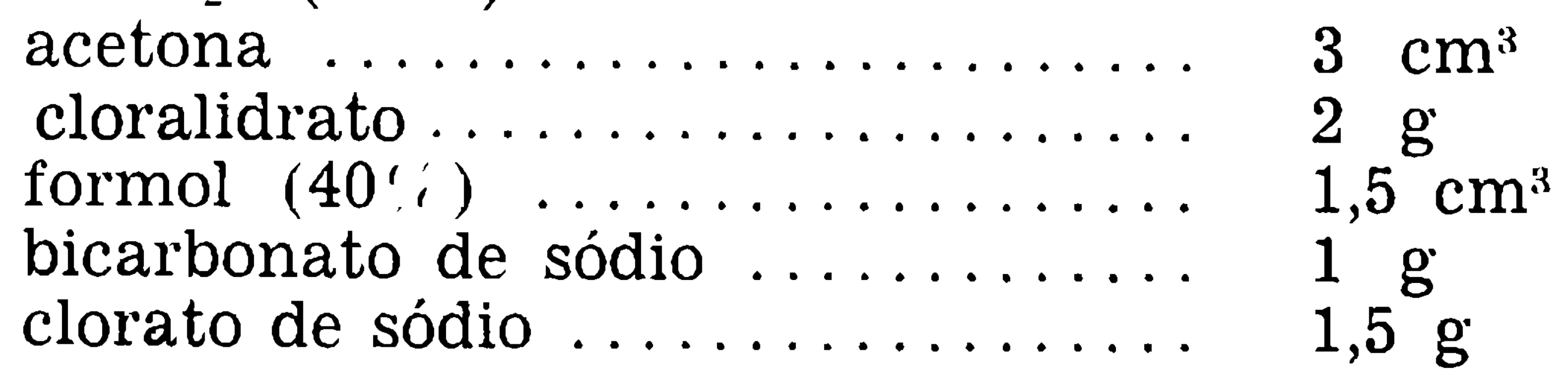


Método conforme JoRRes:

(veja também a referência inicial ao método anterior).

Líquido de preparação:

em $200 \mathrm{~cm}^{3} \mathrm{H}_{2} \mathrm{O}$ (dist.) :

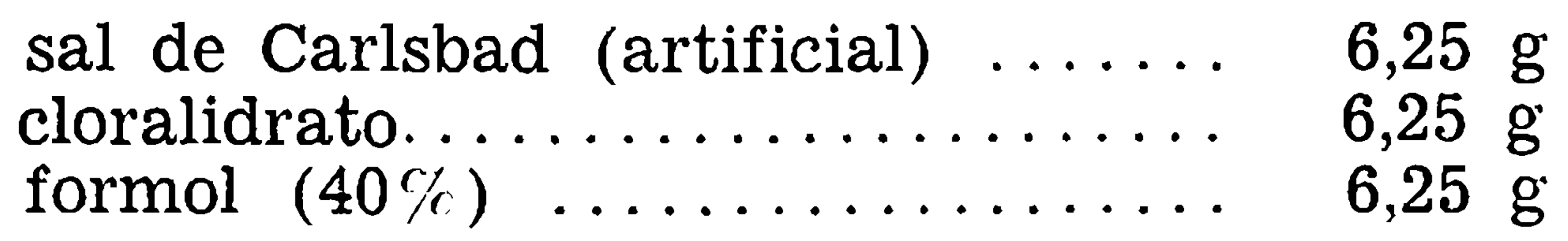

Nêsse soluto ficam peças menores durante dois dias, maiores até 8 dias. Depois lavagem em $\mathrm{H}_{2} 0$ (corrente) durante 12 horas ou mais e passagem para o:

Líquido de conservação:

em $200 \mathrm{~cm}^{3} \mathrm{H}_{2} 0$ (dist.)

açúcar de cana ............ 62,5 g

acetato de potássio ............ 4 g

sulfato de potássio ............ $2 \mathrm{~g}$

Composição de sal de Carlsbad (artificial) é a seguinte:

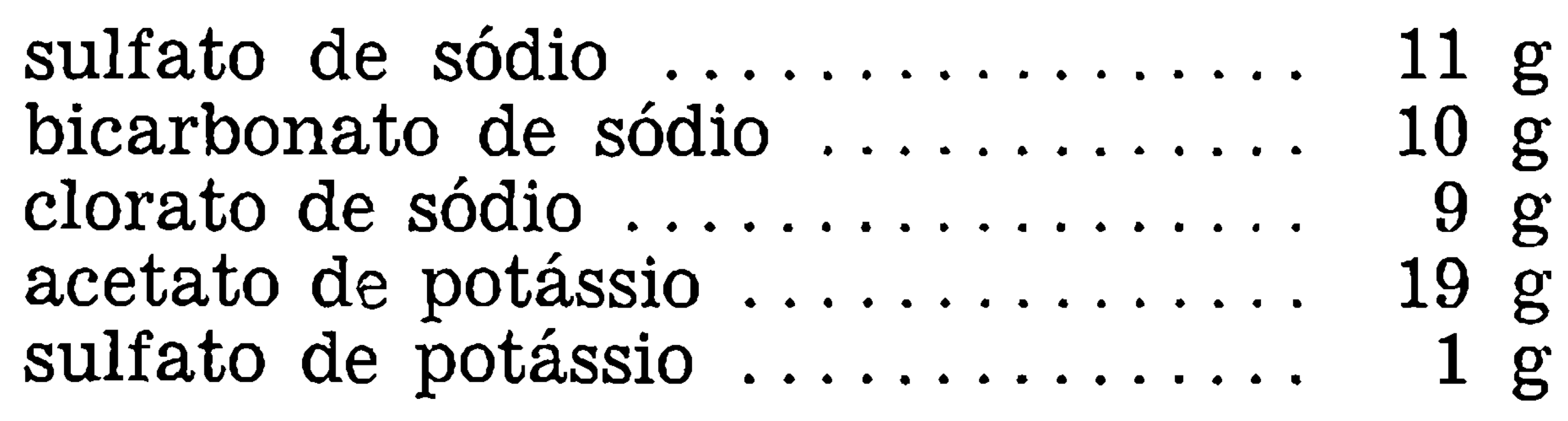

27. Dissecação de um inseto: A dissecação de um inseto, principalmente de um menor exige muitas horas ou até dias. Quando estiver com pressa nem vale a pena de começar, pois não chegará a um resultado. Anexo a que atrapalham e as massas das extremidades serão separados dentro das possibilidades. Segue a abertura do organismo que nunca deverá ser feita por um corte ventral, pois destrói o sistema nervoso. A abertura deve ser feita segundo a finalidade por um corte longitudinal da linha dorsal ou de uma das linhas laterais. Por exemplo numa largata o corte vai até a cápsula craniana, no inseto adulto até o metatorax e daqui na membrana intersegmental entre torax e abdomen até as linhas laterais num corte dorsal, até a outra linha lateral num corte lateral. Freqüentemente deve-se fazer um corte através de ambas as linhas laterais (principalmente em coleópteros e heterópteros). A retirada da placa dorsal é feita cuidadosamente em água (ou em soluto isotónico quando os objetos devem ser posteriormente examinados histològicamente). Para isto segura-se o inseto numa placa de dissecação com alfinetes de aço inoxidável de forma que os alfinetes não perturbam a dissecação.

28. Preparo de placas de preparação. E melhor trabalhar com uma placa metálica laqueada de côr preta ou uma tal de metal ino- 
xidável com margens inclinadas (base 10 por 15 centímetros, profundidade 7 centímetros, sendo que as margens medem nas suas extremidades 20 respectivamente $25 \mathrm{~cm}$ ). No fundo das placas coloca-se turfa de $2 \mathrm{~cm}$ de grossura cobrindo tanto com parafina a qual juntou-se um soluto de borracha natural a $10 \%$ até a imbibição da turfa deixando-se formar ainda por cima uma camada de $1 \mathrm{~cm}$ de parafina (em banho maria). Quando formam-se bolhas de ar deve-se aquecer mais algumas vêzes.

Soluto: Soluto de borracha: borracha natural não vulcanisada é partida e tanto do mesmo dissolvido em clorofórmio até o soluto ainda passa pelo filtro. O filtrado é adicionado na porcentagem descrita à parafina líquida e a mistura aquecida numa placa ampla em banho maria até o desaparecimento do cheiro de clorofórmio. A parafina é de uma côr amarela-marrom (para o preparo de placas de preparação pode utilisar-se de parafina não purificada).

29. Dentro das possibilidades separa-se os órgãos internos retirando as partes maiores e não necessárias como traquéias ou corpos gorduroros sem prejudicar os outros órgãos. Em seguida simultâneamente a fixação e a coloração. De acôrdo com a finalidade o líquido compõe-se de diversos componentes:

30. Como soluto-mãe emprega-se $80 \mathrm{~cm}^{3}$ álcool de $60 \%$ com 10 $\mathrm{cm}^{3}$ de formol.

31. Adiciona-se $5 \mathrm{~cm}^{3}$ de vermelho neutro $(1 \%$ em $\mathrm{H} .0)$ e $2 \mathrm{~cm}^{3}$ de azul de metilena ( $1 \%$ em $\mathrm{H}_{2} 0$ ) ou $1 \mathrm{~cm}^{3}$ de verde brilhante $(1 \%$ em $\left.\mathrm{H}_{\Perp} 0\right)$. Duração de 20 a 30 minutos. Os preparados com coloração excessiva são diferenciados com álcool de $96 \%$. Êsse método serve para preparados inteiros.

32. Para preparação de partes finas dos órgãos é mais apropriado a seguinte composição: ela trabalha mais devagar proporcionando uma coloração mais uniforme de todos os órgãos também dos mais profundos: $90 \mathrm{~cm}^{3}$ de álcool de $60 \%, 5 \mathrm{~cm}^{3}$ de formol, $1 \mathrm{~cm}^{\prime \prime}$ de vermelho neutro $\left(0,5 \%\right.$ em $\left.\mathrm{H}_{2} \mathrm{O}\right) 1 \mathrm{~cm}^{3}$ de azul de metilena $(0,5 \% \mathrm{em}$ $\left.\mathrm{H}_{.} 0\right)$ ou $1 \mathrm{~cm}^{*}$ verde brilhante $\left(0,5 \%\right.$ em $\left.\mathrm{H}_{.0}\right)$. Duração de 1 a 2 dias diferenciando em seguida em álcool de $40 \%$.

33. Para a coloração específica dos corpos gordurosos o objeto dissecado é molhado com um soluto saturado de sudan III em álcool a $70 \%$.

34. Para a coloração especializada dos músculos lança-se mão de uma adição de $5 \%$ de orange GG (soluto saturado em $\mathrm{H}_{2} 0$ ) à soluto-mãe. 
III. Fixação.

35. Gerais: sôbre os princípios da fixação partindo dos diversos pontos de vista veja Zeiger (1938), Werner (1934-1937) e SEKI (1937).

36. Para fins histológicos e citológicos nunca é suficiente uma única fixação mas sim devem-se empregar métodos diversos pois as misturas diferentes apresentam as estruturas plasmáticas mais finas em forma variada. É necessária uma fixação perfeita e exata pois ela é a base para a posterior coloração.

37. Falhas, principalmente insuficiente capacidade da coloração causada pelo emprêgo de meios de fixação não propriados podem ser diminuídas em certos casos por uma refixação.

38. Freqüentemente empregam-se misturas de líquidos como fixadores, raramente líquidos isolados.

39. As misturas seguintes de líquidos aprovaram para insetos:

apropriadas para:

aspetos gerais

núcleos

citoplasma

estruturas fibrilosas

nervos

gorduras e óleos

esfregaços

quitina

ovos e embriões líquido segundo:

Carnoy, Bouin, Gilson, Susa de Heidenhain, Zenker

Carnoy, Bouin, Flemming, Gilson

Carnoy, Bouin, Flemming

Susa de Heidenhain

Mueller, Burke, Orth

Flemming

vapores de ácido ósmico puro,

Susa de Heidenhain

Carnoy, Bouin, Gilson, P. Mayer

Petrunkewitsch

40. Execução e prática da fixação: o inseto morto deve ser desengordurado externamente antes da fixação pois freqüentemente as gorduras e cêras aderentes dificultam a penetração dos líquidos. Para isto mergulha-se o inseto algumas vêzes ràpidamente em éter. Ao mesmo tempo o éter elimina o ar aderente e uma parte do ar nas traquéias. O inseto ainda úmido pelo éter é colocado no líquido da fixação.

41. Como durante a fixação juntam-se líquidos pesados no fundo da placa, leves na superfície do fixador, deve-se deitar o objeto ou num pedaço de algodão ou de gaze ou ser pendurado na parte central do vidro. Interessante são tubinhos de vidro de larguras várias fechadas numa extremidade com gaze de uma tela de diâmetro grosso. $\mathrm{Na}$ outra extremidade puxa-se uma alça de vidro. Dêste modo o líquido pode sair e o fixador tem livre entrada ao objeto por todos os lados. Ao mesmo tempo é facilitado a passagem para outros líquidos. Du- 
rante esta passagem deve-se prestar atenção que quanto menos possível entrem restos do primeiro líquido no segundo.

42. No caso de insetos maiores deve-se retirar o objeto depois de certo tempo para cortar-lo para que o fixador possa entrar com mais rapidez e maior uniformidade. Deve-se evitar de cortar o objeto antes da fixação pois podia perder-se órgãos ou partes de órgãos ou provocar deslocamentos. Sòmente depois de uma fixação superficial pode-se proceder ao corte sem preocupações. Evita-se trabalhar com tesouras, para evitar contusões, trabalha-se com lâminas de gilete.

43. Para a fixação de insetos inteiros de mais de $1 \mathrm{~cm}$ de comprimento recomenda-se uma injeção com o fixador. Para não rasgar as partes deve-se injetar só tanto líquido até que as membranas segmentais começam esticar-se. Quando se providencia pela saída do líquido, pode-se lavar a cavidade abdominal.

44. A injeção deve ser feito devagar para dar tempo à musculatura de turgor desceder à nova pressão paulatinamente.

45. No caso que se desejar fixar um grande inseto como inteiro e não está indicado uma injeção, é melhor de empregar como fixador sòmente um líquido não uma mistura. No caso de misturas freqüentemente um componente avança consideràvelmente assim que na parte interna êste componente, nas partes externas aquêle produz efeito. Por exemplo na fixação com líquido de Flemming a parte interna de um objeto maior é fixado principalmente pelo ácido acético, as partes externas porém mais pelo tetróxido de ósmio que defunde-se mais devagar.

46. Os fixadores não devem ser utilisados em demasia mas devem ser renovados freqüentemente. Isto deve ser observado principalmente em misturas nas quais entram componentes fàcilmente voláteis pois pela evaporação é alterada a proporção da mistura.

47. A proporção do tamanho do objeto para a quantidade do líquido não deve ser inferior a 1 : 10 (no líquido de Flemming a 1 : 5) . Recomenda-se de movimentar várias vêzes os objetos para que o líquido possa atingi-los uniformemente devendo-se evitar de mexer com as matérias saídas dos objetos que se juntam no fundo do vidro.

48. Fixação por gáses: Para pequenos objetos como conteúdo intestinal, membranas, esfregaços, partes finas de tecidos etc. podem ser impregados gáses de ácido ósmico (tetróxideo de ósmio, OsO.), formaldehide ou iôdo. A fixação procede-se ràpidamente não porém devendo ser recomendado para todas as finalidades histológicas. Serve porém para preparados em geral e em investigações microanatómicas.

49. Fixação com gáses do ácido ósmico. Recomenda-se principalmente para a prova de gorduras, óleos, cêra etc. que são escurici- 
dos pelo $\mathrm{OsO}_{4}$. As modificações da forma são mínimas. Emprega-se um soluto de $1 \%$ a $2 \%$ em água ou em ácido crômico. Os preparados recentes são deitados pendurando por baixo da lâmina, esfregaços com a prate superior para baixo, numa pequena placa de vidro com $0 \mathrm{SO}_{+}$ assim que o objeto fica quase $1 \mathrm{~cm}$ por cima do líquido (bastam poucas gotas). A placa deve ser fechada evtl. por meio de outras lâminas várias. O efeito dos gáses para os esfregaços e outros preparados finos durante 1 a 2 minutos, para preparados mais grossos durante 1 a 2 horas. Cuidado: os gáses são tóxicos.

Soluto: Preparo do soluto do $0 \mathrm{~s}_{4}$ : para evitar a redução do ácido ósmico por impurezas de partes orgânicas deve-se evitar no preparo do soluto dos cristais poeira ou qualquer impureza. Melhor do que em $\mathrm{H}_{2} 0$ (dist.) conserva-se $0 \mathrm{~s}_{4}$ num soluto de ácido crômico a $0,1 \%$ (Romeis) : $0,1 \mathrm{~g}$ de ácido crômico em $100 \mathrm{~cm}^{3} \mathrm{H}_{2} 0$, depois da solução iun$\operatorname{tar} 1$ ou $2 \mathrm{~g}$ ( $1 \%$ ou $2 \%$ ) $\mathrm{OsO}_{4}$ : A ampola bem limpa, na qual é vendida o $0 \mathrm{~s}_{4}$, é aberta na parte central e deitado então com os cristais no ácido crômico. A dissolução exige algumas horas.

50. Fixação com vapores de iôdo: Num tubo de vidro aquece-se alguns pequenos cristais de iôdo até que o vidro enche-se com vapores de iôdo (vapor de iôdo é mais pesado do que o ar e de côr marrom). Os vapores deixam-se deitar sôbre o objeto colocado numa placa. Tempo de ação 2 a 3 minutos. Em seguida o objeto deve ser aquecido durante 2 a 3 minutos a $40^{\circ}$ para dispersar o iôdo livre.

51. Fixação com gáses de formaldehide (soluto de quase $40 \%$ de vapores de formaldehide em $\mathrm{H}_{2} 0=$ formol) : um pedaço de papel de filtro molhado com formaldehide puro deita-se junto com o objeto numa placa de vidro fechada. Os vapores necessitam uma meia até uma hora para a fixação. O tempo pode ser reduzido a um têrço quando realiza-se a fixação no dessecador aquecido na estufa a $60 \%$.

52. Álcool. Se não se trata de outra forma, trata-se no seguinte de álcool etílico puro.

53. Álcool age por desidratação fortemente diminuindo, dissolve gorduras, materias graxas, numerosas secreções, celesterina e substância cromafina. Quimicamente êle é indiferente, fixando o que se consegue fracamente ou não com outros líquidos, entre outros ácido úrico, glicogênio, ferro, cálcio e mucina. Reduz-se fortemente plasma e núcleo da mesma forma porém menos. A capacidade de coloração é boa para quase todos os métodos, a capacidade de cortar é reduzida.

54. Aplicação: Objetos com uma grossura não superior a $5 \mathrm{~mm}$. Se possível deve-se separar antes as partes quitinosas e músculos pois êstes ressecam pela desidratação. Objetos fixados podem ser conservados em álcool a $80 \%$. Com mais eficiência e maior rapidez do que o álcool absoluto penetra o álcool comum que sempre tem $1 \%$ a $2 \%$, 
freqüentemente a $3 \% \mathrm{H}_{2} 0$, os tecidos. Duração da fixação de objetos pequenos e insetos cortados de 2 a 3 horas, fora disto 4 a 5 horas.

55. Sublimado: isoladamente tem uma ação de diminuição sôbre plasma, menos sôbre o núcleo. Principalmente indicado para fixação de albuminas. Os lipóides etc. são dissolvidos. Sublimado penetra ràpidamente reduzindo-se porém a entrada devido aos produtos de fixação que surgem. Emprega-se para diminuir esta redução não o soluto aquoso de saturação completa mas sim a da saturação para metade. Duração em pequenos objetos e insetos cortados de 3 a 4 horas, fora disto 6 a 8 horas.

Soluto: soluto saturado em $\mathrm{H}_{.2} 0: 200 \mathrm{~cm}^{3} \mathrm{H}_{20} 0$ (dist.) são fervidos num balão de $1 \mathrm{ltr}$. depois de apagado o fogo adiciona-se devagar $15 \mathrm{~g}$ de sublimado (cloreto de mercúrio) mexendo várias vêzes durante o processo de resfriamento. O $\mathrm{H}_{. .0}$ deve ser puro. Para a fixação é diluído para a metade com $\mathrm{H}_{20} \mathrm{O}$ (dist.) .

56. Formol. O formol comercial corresponde a um soluto de $40 \%$ do gás de formaldehide em $\mathrm{H}_{. .} 0$. Êste formol comercial tem reação sempre ácida (ácido fórmico), e assim êle deve ser neutralisado para determinados métodos se e imoossível de comprar um produto estandardizado. Deve ser protegido da luz.

57. Neutralisação do formol: num vidro escuro adiciona-se ao formol carbonato de cálcio em pó agitando-se o freqüentemente e conservando o com carbonato. $\mathrm{p}_{\text {II }}$ quase 6,5.

58. Formol penetra ràpidamente os tecidos, endurece relativamente pouco, a diminuição é de quase 5 a $8 \%$ atingindo porém no tratamento seguinte $25 \%$. Certas gorduras e lipóides bem como nervos são muito bem fixados. O formol não presta-se para a fixação de nâcleos, ácido úrico, glicogênio e guanina.

59. Diluição do formol: para evitar erros são indicados no seguinte as partes de água e de formol e o conteúdo procentual do formol: por exemplo formol $(40 \%) 1: 3=1$ parte de formol a $40 \% \mathrm{em}$ 3 partes de água. Para evitar a reação ligeiramente ácida emprega-se para a diluição sempre água corrente.

60. Refixação depois da fixação com formol puro é praticável com as misturas usuais.

61. Depósitos de formol que podem-se formar podem ser desmanchados colocando os cortes num soluto de 2,5 , $_{c}^{\prime}$ amoníaco $\left(\mathrm{NH}_{4} \mathrm{OH}\right)$ em álcool a 70!: .

62. Na combinação com outros líquidos o formol sòmente pode ser adicionado antes do uso para evitar decomposições. 
63. Ácido acético: emprega-se sòmente em casos especiais. Dis. solve parcialmente o plasma e produz imbibições fixando porém muito bem os núcleos empregando um soluto de $1 \%$ em $\mathrm{H}_{2} 0$. Duração de 1 a 2 horas em objetos maiores até 4 horas.

64. Sob ácido acético atende-se a solução de $96 \%$ em $\mathrm{H}_{2} 0$, soí ácido acético glacial o ácido de $100 \%$.

65. Depois da fixação com ácido acético os preparados devem ser colocados imediatamente em álcool de $96 \%$ para evitar dilatações.

66. Ácido ósmic: por causa da sua rapidez difusora reduzida o $\mathrm{OSO}_{4}$ isolado é empregado raras vêzes. Como o $0 \mathrm{SO}_{4}$ é reduzido fàcilmente por substâncias orgânicas Romeis recomenda um soluto de ácido crómico de $0,1 \%$ (veja n..$^{\circ} 49$ ). Êste soluto conserva-se quando bem fechado (sòmente vidro de Pyrex ou de Jena).

67. $0 \mathrm{~s}_{4}$ fixa muito bem as estruturas celulares, a diminuição é pouca. Gordura e lipóides são estabilizados e tingidos de marrom a
prêto.

68. Para esfregaços e membranas recomenda-se mais os gáses (veja n. ${ }^{\circ} 49$ ).

69. Preparo do soluto veja n. ${ }^{\circ} 49$.

70. As gorduras escurecidas podem ser clarificadas com permanganato de potássio, ácido oxálico ou água oxigenada.

71. Álcool-ácido acético glacial: $20 \mathrm{~cm}^{3}$ de ácido acético glacial em $100 \mathrm{~cm}^{3}$ de álcool absoluto. Penetra mais ràpidamente do que o álcool. A diminuição é um pouco menor do que com álcool isolado. Como desvantagem surge uma dissolução parcial das estruturas plasmáticas podendo empregado assim só em casos isolados. Duração de 2 a 5 horas conforme o tamanho do objeto. Em seguida lavar em álcool absoluto durante 20 a 30 minutos.

72. Mistura de Carnoy. Composição: 6 partes de álcool absoluto, 3 partes de clorofórmio, 1 parte de ácido acético glacial. Não há necessidade de desengordurar os objetos anteriormente pois o clorofórmio dissolve as gorduras. Duração de 1 a 2 horas, objetos maiores até 5 horas. Permanência maior em "Carnoy" prejudica de forma que substâncias grodurosas são extraídas com mais freqüência e as estruturas fibrilosas são imbibidas principalmente quando pelo evaporação do clorofórmio e do álcool aumenta a percentagem do ácido acético. O soluto deve ser preparado cada vez novamente, pois pela evaporação alteram-se ràpidamente as concentrações. Logo depois da fixação lavar em álcool a $96 \%$ (mudar duas vêzes principalmente antes da coloração com hematoxilinas) . 
73. Mistura de Orth: principalmente para fixação da substância nervosa. Composição: $2,5 \mathrm{~g}$ bicromato de potássio em $100 \mathrm{~cm}^{3} \mathrm{H}_{.0} 0$ como soluto mãe a qual adiciona-se imediatamente antes do uso 10 $\mathrm{cm}^{3}$ de formol. Fixação no escuro durante 24 a 48 horas. Depois lavar em $\mathrm{H}_{.20}$ (corr.) durante 24 horas deshidratar sob benzol. Depósitos dos líquidos que contém cromo são eliminados pela colocação antes da desidratação em ácido crômico de $0,5 \%$.

74. Líquido de Flemming: composição: soluto-mãe: $0,5 \mathrm{~g} \quad 0 \mathrm{~s} 0_{4}$ são dissolvidas em $120 \mathrm{~cm}^{3}$ de um ácido crômico de $0,1 \%$. A $19 \mathrm{~cm}^{3}$ dêste soluto junta-se antes do uso $1 \mathrm{~cm}^{3}$ de ácido acético glacial. $\mathrm{O}$ soluto penetra devagar podendo ser fixadas sòmente peças pequenas de uma grossura de 1 a $3 \mathrm{~mm}$. Duração de 24 horas até alguns dias mesmo a permanência durante alguns meses não é desvantajosa. Em seguida lavar em água corrente durante 24 horas e desidratar sob benzol.

75. Líquido de Bouin: a mistura de Bouin penetra nos insetos sòmente devagar por falta de álcool. Melhor é a modificação Duboscq-Brasil (1905): Composição: $1 \mathrm{~g}$ de ácido pírcicro em $150 \mathrm{~cm}^{3}$ de álcool a $80 \%$ adicionando-se a êsse soluto mãe antes do uso formol $(40 \%)$ $60 \mathrm{~cm}^{3}$ e ácido acético glacial $15 \mathrm{~cm}^{3}$. Duração conforme o tamanho dos objetos de 2 a 24 horas. Permanência durante alguns dias nêste fixador não é desvantajosa. Lavagem diretamente em álcool a $80 \%$ que deve ser mudado algumas vêzes.

76. Ácido pírico - ácido nítrico segundo P. MAYer. Penetra ràpidamente apropriado principalmente para a investigação da quitina pois esta é desincrustada até um certo grau. Composição: $100 \mathrm{~cm}^{3}$ $\mathrm{H}_{2} 0,5 \mathrm{~cm}:$ de ácido nítrico $\left(\mathrm{HNO}_{\text {: }}\right.$ de peso específico 1,153$)$ e ácido pícrico (em substância) até a saturação. Depois de 24 horas filtrar. No caso que formar se mais depósito deve-se filtrar mais uma vez 24 a 48 horas após. O filtrado claro fixa pequenos insetos em 3 a 6 horas grandes em 12 horas. Lavagem direita em álcool a $70 \%$.

77. Líquido de Gilson: penetra ràpidamente e fixa uniformemente. Composição: sublimado $20 \mathrm{~g}$, álcool a $60 \% 100 \mathrm{~cm}^{3}, \mathrm{H}_{.: 0}$ (dist.) $880 \mathrm{~cm}^{3}$, ácido nítrico (peso específico 1,456) $15 \mathrm{~cm}^{3}$, ácido acético glacial $4 \mathrm{~cm}^{3}$.
a) desengordurar o inseto morto,
b) fixação, duração de 1 a 3 horas, objetos maiores até 5 horas,
c) álcool a 70\% com 5 a 6 gotas de um soluto de iôdo com ioda- to de potássio (para a eliminação dos depósitos de sublimado), eventualmente pode-se empregar também tintura alcoólica de iôdo,
d) série com álcool e benzol até parafina. 
Os cortes devem ser tratados após de diluição da parafina em álcool a 70\% mais uma vez durante 1 minuto com iôdo (veja em cima sob c)). Para a retirada do iôdo os cortes devem ser colocados durante 2 a 3 minutos num soluto de $0,25 \%$ de tiosulfato de sódio. Este último soluto deve ser renovado correntemente.

Soluto de iôdo com jodato de potássio: $2 \mathrm{~g}$ de $\mathrm{J}_{2 .}$ e $3 \mathrm{~g}$ iJ em $10^{\prime}$ ) $\mathrm{cm}^{3}$ de álcool a $90 \%$. Tintura alcoólica de iôdo: $10 \mathrm{~g}$ de iôdo metálico em $100 \mathrm{~cm}^{3}$ de álcool a $90 \%$.

78. Líquido de Zenker: penetração relativamente rápida, objetos possivelmente não maiores do que $5 \mathrm{~cm}$. Composição: bicromato de potássio $3 \mathrm{~g}$ em $100 \mathrm{~cm}^{3} \mathrm{H}_{2} 0$ (dist.) adicionando $5 \mathrm{~g}$ de sublimado. A êsse soluto-mãe junta-se antes do uso $5 \mathrm{~cm}^{3}$ ácido acético glacial. Fixação durante 1 a 24 horas conforme o tamanho do objeto, lavagem em água corrente durante 24 horas e série com álcool com adição de iôdo em álcool a $70 \%$ (veja n. ${ }^{\circ} 77 \mathrm{c}$ ). Os cortes devem ser tratados como na fixação segundo Grlson .

79. "Susa" segundo Heidenhain: êsse método descalcifica devi. do a adição de ácido tricloracético, recomendável para insetos com fortes incrustações. Composição: sublimado $4,5 \mathrm{~g}$, cloreto de sódio $(\mathrm{NaCl}$ quìmicamente puro) $0,5 \mathrm{~g}, \mathrm{H}_{2} \mathrm{O}$ (dist.) $80 \mathrm{~cm}$ :", ácido tricloracético 2 $\mathrm{g}$, ácido acético glacial $4 \mathrm{~cm}^{3}$, formol $(40 \%) 20 \mathrm{~cm}^{3}$.

a) fixação conforme o tamanho durante 1 a 24 horas,

b) álcool a $90 \%$ mudando 2 a 3 vêzes,

c) álcool a $70 \%$ com adição de iôdo (veja n. ${ }^{\circ}$ 77),

d) deshidratar.

Tratamento posterior dos cortes como em n. 77.

80. Líquido conforme Petrunkewitsch: presta-se como o líquido de Gilson para quitina, mas também para ovos e embriões. Composição: $\mathrm{H}_{2} \mathrm{O}$ (dist.) $300 \mathrm{~cm}^{3}$, álcool absoluto $200 \mathrm{~cm}^{3}$, ácido acético glacial $90 \mathrm{~cm}^{3}$, ácido nítrico (peso específico 1,456) $10 \mathrm{~cm}^{3}$, sublimado até a saturação. Uso como sob n..$^{\circ} 7$ devendo ser dobrado o tempo da fixação quando tratar-se de ovos e embriões, pupas e objetos semelhantes.

81. Para a fixação das substâncias dos nervos presta-se principalmente a mistura conforme Burke: composição: $\mathrm{H}_{2} 0$ (dist.) $75 \mathrm{~cm}^{3}$, formol $(40 \%) 25 \mathrm{~cm}^{3}$, piridina (pura) $5 \mathrm{~cm}^{3}$. O líquido deve ser 20 vêzes mais do volume do objeto:

a) fixação durante 48 horas até algumas semanas, permanência maior não prejudica,

b) lavar em álcool a $90 \%$,

c) desidratar. 
IV. Desidratação.

82. Como nos insetos a substituição da água nos tecidos pelo álcool processa-se muito lentamente e raras vêzes completamente, não pode-se trabalhar com um método comum para tecidos moles o mais ou menos homogêneos. Pequenos restos de água (principalmente na quitina) influenciam a capacidade de cortar o objeto tanto que ficam apenas pedaços parciais. Êste perigo ainda é aumentado pelo álcool absoluto que (quando $100 \%$ ) já após poucas horas absorveu tanta água do ar que uma desidratação completa não é mais possível. E um velho problema na histologia procurar de evitar o álcool absoluto o que foi resolvido por vários desvios (dioxan, benzoato de metila etc.) . Para insetos ainda existiam dificuldades com os métodos recomendados referente a capacidade de cortar partes do endosceleto nas quais ainda permaneciam restos de água pois os líquidos intermediários não conseguiram tirar completamente o álcool com os restos de água.

83. O método atual com qual também podem ser cortados os insetos mais duros numa série ininterrupta, é o seguinte, que KIESSER (1929) também empregava para objetos botânicos em forma semelhante. Após da fixação em fixadores aquósos:

a) $\mathrm{H}_{.0} \mathrm{O}$ (dist.) durante 6 horas,

b) álcool a $40 \%$ durante 4 horas,

c) álcool a $60 \%$ durante 4 horas,

d) álcool a $70 \%$ durante 12 horas,

e) álcool a $80 \%$ durante 12 horas,

f) álcool a $96 \%$ (correspondendo ao álcool absoluto comercial) durante 24 horas,

g) álcool a $96 \% 3$ partes e benzol 1 parte durante 12 horas,

h) álcool a $96 \% 1$ parte e benzol 1 parte durante 12 horas,

i) álcool a $96 \% 1$ parte e benzol 3 partes durante 12 horas,

k) álcool a $96 \% 7$ partes e benzol 100 partes durante 24 horas,

l) benzol puro durante 6 horas,

m) benzol puro durante 12 horas,

n) soluto saturado de parafina (ponto de fusão $56^{\circ}$ a $58^{\circ}$ ) em benzol puro durante 12 horas,

o) parafina pura, líquida na estufa de $60^{\circ}$ a $61^{\circ}$ durante 2 dias.

84. Os tempos indicados referem-se à insetos não cortados de $\mathbf{5}$ a $10 \mathrm{~mm}$ de comprimento e são tempos mínimos não podendo ser inferiores, mas sim superiores.

85. Após a fixação em líquidos com álcool começa-se com a série com álcool correspondente, p.e. após a fixação em líquido de Carnoy lavar direitamente em álcool a $98 \%$. 
86. Se não é intenção de cortar os preparados, basta a série pequena com álcool:

a) álcool a $40 \%$ durante 2 a 3 horas,

b) álcool a $70 \%$ durante 3 a 4 horas,

c) álcool a $96 \%$ durante 8 a 10 horas,

d) álcool absoluto (à qual adiciona-se para a desidratação alguns pedaços de sulfato de cobre queimado $\left(\mathrm{CuSO}_{4}\right)$ o que produz porém uma ligeira acidificação. A desidratação também nunca sai completa. Êste álcool deve ser mudado 1 ou 2 vêzes cada 12 horas,

e) xilol, muda $1 \mathrm{vez}$, cada 12 horas,

f) bálsamo de canada.

Os tempos referem-se aos insetos não cortados de 5 a $10 \mathrm{~mm}$ de comprimento .

87. Diluição de líquidos.

a) Conhecido é a diluição de a $\%$, procura-se a de $b \%$ : à b partes da primeira adiciona-se $(a-b)$ partes do meio de diluição para conseguir a partes da soluçáo de $b \%$.

b) conhecida é a diluição 1 : a, procura-se a de 1 : b: à a partes da primeira adciona-se $(b-a)$ partes do meio de diluição para conseguir $b$ partes da diluição de $1: b$.

88. Na desidratação deve-se prestar atenção que os objetos como na fixação (veja sob n. ${ }^{\circ} 41$ ) estejam colocados na parte central do líquido, pelo menos numa base de algodão de vidro, algodão ou gaze.

V. Inclusão.

89. Como meio de inclusão a parafina tem as maiores vantagens. Permita a grossura mínima do corte, facilita o corte de séries e penetra uniformemente no objeto.

90. O micrótomo de gêlo não aprovou em geral para os insetos prestando-se mais para partes de tecidos entre si ligadas.

91. A parafina geralmente usada em trabalhos histológicos com o ponto de fusão de $56^{\circ}$ a $58^{\circ}$ demonstra-se em muitos casos dura demais.

92. Atualmente emprega-se com ótimo resultado uma parafina aborrachada: A 95 partes de paarfina com ponto de fusão de $56^{\circ}$ a $58^{\circ}$ adiciona-se em estado líquido 5 partes de um soluto aborrachado conforme foi descrita sob n. ${ }^{\circ} 28$. 
93. Os objetos não devem ficar por pouco tempo na parafina quente. O endurecimento segundo experiências feitas aqui não aumenta na estufa quando água e álcool foram tirados completamente. O benzol escapa relativamente depressa em poucas horas. Para não provocar um enrequessimento de vapores de benzol na parafina, é indicado de tempos e tempos tirar o ar com os gáses da estufa com ajuda de uma bomba de jato de água.

94. A temperatura da estufa deve ser entre $60^{\circ}$ e $61^{\circ}$.

Com temperatura inferior a velocidade de penetração da parafina principalmente em insetos é reduzida.

95. Para a inclusão de insetos maiores bastam vidros normais de relógio de $8 \mathrm{~cm}$ de diâmetro e de $1 \mathrm{~cm}$ de profundidade. Para objetos maiores prestam-se placas coniformes de vidro ou porcelana com várias profundidades.

86. Para objetos maiores podem-se empregar com vantagem molduras de metal que constam de uma placa básica polida de um metal não oxidável e de 2 peças retangulares que também são polidas ou pelo menos esmeriladas. Pela modificação das peças nos ângulos que tem uma altura de $1,5 \mathrm{~cm}$ e uma grossura idêntica podem-se conseguir todas as formas do bloco de parafina.

97. Antes de deitar a parafina no vidro deve-se passar êste um pouco de glicerina o que pode-se dispensar quando trata-se de metal polido.

98. Quando a parafina mostrar uma superfície endurecida os objetos orientados não podem ser mais movidos, deita-se as plaquinhas na água ou ponha a forma numa placa juntando água que porém não deve chegar na superfície da parafina. Deve-se evitar a submersão até que a superfície do bloco seja totalmente endurecido. Endurecimento sem esfriamento por água dá blocos desiguais.

\section{Cortes.}

99. A grossura de corte mais favorável está entre 5 e 10 micra. Depois de uma inclusão perfeita tornam-se possíveis cortes de 2 micra de grossura. Parafina aborrachada começa enrolar em cortes com 15 micra de grossura.

100. No corte de objetos entomológicos deve-se prestar atenção que o corte seja feito uniforme e não devagar demais.

101. O comprimento da fita de cortes conexos não deve ser demais. Deve-se deixar na lâmina suficiente espaço que os cortes possam esticar-se na direção longitudinal da fita. Com grossura de corte reduzida dá-se o juntamento dos cortes numa proporção maior do que com uma grossura maior. 
102. Deve-se colar os cortes com muito cuidado pois o corte de um inseto compõem-se normalmente de numerosas partes soltas.

103. A lâmina cuidadosamente limpa é esfregada com uma pequena gota de glicerina com albumina com o dedão com pressão até que o vidro seja coberto de uma camada uniforme bem visível de glicerina com albumina. Em seguida deitam-se 3 a 4 gotas $\mathrm{H}_{2} \mathrm{O}$ (dist.) que espalham-se ràpidamente e uniformemente sôbre a lâmina.

Soluto: Partes iguais de glicerina pura e albumina (clara de ovo) de um ovo fresco de galinha são misturadas fortemente e filtradas. Junta-se na proporção de $1 \%$ formol contra formação de cogumelos ou ácido tímico na mesma forma.

104. As fitas de cortes são tiradas com um pincel da navalha e colocadas da esquerda a direita em seqüência por sôbre a camada aquosa.

105. A lâmina é deitada numa placa elétrica com $45^{\circ}$ a $55^{\circ}$, não mais para não desmanchar a parafina, ou numa mesa metálica aquecida a gás. Para distribuição uniforme do calor pinga-se antes um pouco de água sôbre o qual coloca-se a lâmina. Os cortes estendem-se aqui visìvelmente até o tamanho quase normal que é atingido quando desaparecem as dobras (visível quando olhado lateralmente).

106. A água é tirada da lámina. Deve-se prestar atenção que os cortes ficam na mesma ordem. Com um pincel as fitas de cortes podem ser movidas cuidadosamente.

107. As láminas coloca-se então num ponto menos quente da placa para secar.

108. Não deve-se esquecer de enumerar a lámina antes de esfregar a glicerina. E melhor utilisar-se para isto um diamante de escrever normal.

\section{Coloração.}

109. Antes de cada coloração deve-se lembrar bem quais as substâncias no corte que deseja-se corar principalmente. Disto depende a escolha do método de coloração que depende da natureza da substância a ser tingida e ainda da natureza da substância que tinge.

110. O seguinte resumo dá uma pequena idéia das múltiplas possibilidades:

1. Grupo das anelinas:

anelinas básicas constantes de um corpo cromogénio e de uma cromófora de natureza básica (cromófora são $\mathrm{NH}_{3} \mathrm{NH}$, $\mathrm{CH}_{3}, \mathrm{~N}\left(\mathrm{CH}_{3}\right)_{2}, \mathrm{NH}$ e outras. 
P.e.: fucsina básica, violeta de gentiana, azul de metilena, verde de metilena, tionina, azul de toluidina.

São coloridos especìficamente: oxicromatina dos núcleos, gránulas ácidas dos núcleos e das células, nervos, secreções.

Anilinas básicas dissolvem-se bem em álcool, menos em água. "Uma anilina básica é um corante alcalino ou o sal dêste."

2. Grupo das anelinas:

anelinas ácidas constantes de um corpo cromogêneo e de uma cromófora de natureza ácida (cromóforas são: $\mathrm{OH}, \mathrm{COOH}$, $\mathrm{NO}_{2,}, \mathrm{SO} \mathrm{OH}$ e outras).

P.e.: vermelho de congo, eosina, eritrosina, orange, ácido pícrico, fucsina ácida.

São coloridas especìficamente: basicromatina dos núcleos, plasma e as suas diferenciações até a quitina.

Anilinas ácidas não se dissolvem bem em álcool, mas sim em água .

"Uma anilina ácida é um corante ácido ou o sal dêste".

3. Grupo das anelinas:

anilinas anfóteras constantes de $\mathrm{um}$ corpo cromogêneo com cromóforas básicas e ácidas. O excesso de um grupo determina a natureza da côr.

4. Grupo das anilinas:

anilinas neutras proveniente da reunião de um corante ácido com um corante alcalino como substância nova (não é mistura!).

5. Grupo das anilinas:

anilinas indiferentes constantes de um corpo cromogêneo e de uma cromófora indiferente (cromóforas são: $\mathrm{OCH}_{3}$, $\left.\mathrm{OC}_{2} \mathrm{H}_{3}, 0\right)$.

111. Ficou comprovado que na coloração do corte é mais aconselhável de trabalhar com solutos de coloração fortemente diluídos pois tingem mais uniformemente não deixando flóculos do meio da coloração e não colocando-se por cima das estruturas finas. Em geral um preparado feito assim tem uma coloração mais clara e limpa do que um preparado com solutos concentrados.

112. No caso existe a escolha entre a coloração progressiva e regressiva deve-se preferir o método progressivo com solutos bastante diluídos. A coloração regressiva só devia servir a reprodução de estruturas especiais.

Durante a coloração progressiva é observado o prosseguimento da absorção da côr pelos tecidos até ser atingido o grau de coloração desejado, na coloração regressiva a coloração é sempre exagerada e com um líquido apropriado a côr é extraído até o grau desejado ou destruída.

113. Os cortes secados numa placa de aquecimento (algumas hohas, melhor 24 horas, pois a glicerina evapora devagar!) são passados 
ràpidamente por uma flama de gás até que a parafina começa se difundir. Nisto a albumina coagula na lâmina. Em seguida êles são transportados, possivelmente com parafina líquida, para um vidro de coloração com xilol aonde a parafina se dissolve (duração 5 minutos) . Os cortes são segurados agora pela albumina coagulada no vidro. Dêste momento em adiante os cortes devem ser tratados com o máximo cuidado podendo ser movidos só ligeiramente quando colocados em outros vidros de coloração pois em caso contrário soltam-se partes dos cortes.

114. Não raras vêzes cortes aceitam só ligeiramente anilinas ácidas como orange, eosina, azofloxina, verde de luz, fucsina ácida ou cromotróp $2 \mathrm{R}$. Nesse caso ajuda uma ligeira acidificação do soluto de coloração: uma gota de ácido acético glacial em $100 \mathrm{~cm}^{3}$ do soluto (não mais!).

115. Os cortes são conduzidos através da série com álcool, em cada uma 2 a 3 minutos, como exige cada método de coloração.

116. Carmim com alumen de crômo.

a) Sai de $\mathrm{H}_{2} \mathrm{O}$ (dist.) para: carmim com alumen de crômo 1 a 12 horas (controlar, em caso de excesso de coloração pode ser descolorido com álcool com ácido clorídrico a $0,5 \%$ ),

b) lavar em $\mathrm{H}_{2} \mathrm{O}$ (dist.),

c) série com álcool até $96 \%$, (veja nr. 86),

d) coloração em vermelho de congo 24 horas ou 1 hora em soluto de coloração aquecido até $60^{\circ}$, coloração contraste para quitina,

e) depois do resfriamento lavar em álcool a $96 \%$,

f) série com álcool e xilol e bálsamo.

Resultado: Núcleos azuis escuros ou prêtos, quitina vermelho brilhante, estruturas plasmáticas em diversas tonalidades de cinza a vermelha atenuada.

Solutos: 1. Carmim com alumen de crômo: em $100 \mathrm{~cm}^{3}$ de $\mathrm{H}_{2} \mathrm{O}$ (dist.) de $80^{\circ}$ a $90^{\circ}$ são diluídas 6 gramas de alumen de crômo adicionando-se em seguida $1 \mathrm{~g}$ de carmina e fervendo-se o soluto durante 15 minutos. Depois do resfriamento é filtrado adicionando-se ao filtrado timol ou formol (1\%) contra a formação de cogumelos.

2. Vermelho de congo: $1 \mathrm{~g}$ de vermelho de congo é sacudido em $100 \mathrm{~cm}^{3}$ de álcool a $96 \%$ repetidamente e filtrado depois de 24 horas. Ambos os solutos são estáveis.

117. Hemalumen ácido:

a) de $\mathrm{H}_{2} \mathrm{O}$ (dist.) para hemalumen 4 a 6 minutos ou mais até a completa coloração dos núcleos (controlar), 
b) lavagem em água corrente 30 minutos ou mais.

E bom de colocar os cortes antes da desidratação por 2 a 3 minutos em álcool amoníaco a $1 \%$ quando a água da bica não tem propriedades alcalóides suficientes. Não se deve deixar de lado a lavagem na água corrente pois todas as anilinas com hemateina são extremamente sensíveis para ácidos.

c) série com ácool até a $96 \%$,

d) coloração contraste com vermelho de congo em n. ${ }^{0} 116$.

Resultado: núcleos de azul claro, quitina de vermelho brilhante, tecidos cinzo azuis, estruturas filbrilosas vermelhas atenuadas.

Soluto: hemalumen ácido: em $500 \mathrm{~cm}^{3} \mathrm{H}_{2} 0$ (dist.) são dissolvidas $0,5 \mathrm{~g}$ de hematoxilina adicionando-se exatamente $0,1 \mathrm{~g}$ iodato de sódio $\left(\mathrm{NaJO}_{33}\right)$ como meio de oxidação. Junta-se ainda $25 \mathrm{~g}$ alumen de potássio puro. Depois da dissolução do alumen são adicionadas 25 $\mathrm{g}$ de cloralidrato e $0,5 \mathrm{~g}$ de ácido cítrico cristalisado. O soluto conserva-se $€ m$ vidro neutro.

\section{Hematoxilina de Delafield:}

a) de $H_{.2}$ (dist.) para hematoxilina de Delafield 4 a 5 horas.

b) em caso de excesso de coloração diferenciar em álcool clorídrico (1 gota de ácido clorídrico oficinal em $100 \mathrm{~cm}^{3}$ de álcool absoluto),

c) continuação como em n." 117 b. A lavagem deve ser bastante demorado.

Resultado: Como no hemalumen encontrando-se porém as estruturas plasmáticas coloridas mais forte ou mais fraco em diversos graus. Pode-se eventualmente deixar de lado uma coloração contraste se não é desejada a diferenciação das partes quitinosas (coloração contraste com vermelho de congo) ou se devem ser reproduzidas secreções (coloração contraste com uma anilina destilada de breu) .

Soluto: hematoxilina de Delafield: soluto-mãe: em $200 \mathrm{~cm}^{3}$ de $\mathrm{H}_{:} \mathrm{O}$ (dist.) são dissolvidos $20 \mathrm{~g}$ de alumen amoníaco juntando-se $4 \mathrm{~g}$ de hematoxilina dissolvidas anteriormente em $25 \mathrm{~cm}^{3}$ de álcool absoluto. O soluto deve permanecer aberto e exposto a luz durante 3 a 4 dias sendo filtrado em seguida. Junta-se ao filtrado $50 \mathrm{~cm}^{3}$ de glicerina e $50 \mathrm{~cm}^{3}$ de álcool metílico. Depois de 4 dias durante os quais o soluto fica novamente aberto e exposto a luz, é novamente filtrado. O soluto-mãe conserva-se bem. Para a coloração utilisa-se de $0,5 \mathrm{~cm}^{3}$ do soluto-mãe em $50 \mathrm{~cm}^{\prime \prime}$ de $\mathrm{H}_{. .} 0$ (dist.). No caso que são desejadas estruturas mais finas e interessante de corar com um soluto de meia concentração $\left(0,5 \mathrm{~cm}^{3}\right.$ em $100 \mathrm{~cm}^{3}$ de $\mathrm{H}_{\Perp 0} \mathrm{~d}$ dist. $)$ durante 24 horas. 
119. Hematoxilina férrica de Heidenhain:

a) de $\mathrm{H}_{2} \mathrm{O}$ (dist.) para alumen férrico (2,5\%) 3 a 12 horas.

b) lavagem em $\mathrm{H}_{2} \mathrm{O}$,

c) coloração em hematoxilina 12 a 36 horas (formando-se laca preta de hemateina férrica),

d) alumen férrico $(2,5 \%)$, diferenciar sob contrôle permanente, antes lavar cada vez em água corrente para interromper a diferenciação. Para evitar a destruição da laca de coloração pode-se utilizar pouco antes do término um soluto mais diluído $(1,25 \%)$.

e) lavagem em $\mathrm{H}_{2} \mathrm{O}$ (corr.) 1 hora podendo-se eventualmente colocar antes o corte em água amoníaca $(0,1 \%)$,

f) continuação como em n. ${ }^{\circ} 117$.

Resultado: de acôrdo com o método da fixação e o grau da diferenciação diferentes estruturas são coloridas fortemente prêtas: cromatina, nucléolos, estriação $Q$ e $Z$ e grânulas da musculatura, centrosomos, mitocóndrias, grânulas celulares etc. Os outros tecidos são coloridos em graus vários cinza atenuada ou amarelo. Em geral pode-se deixar de lado a coloração contraste recomendando-se porém a coloração contraste com vermelho de congo para a orientação mais fácil em cortes de insetos (veja n. ${ }^{\circ} 116$ ).

Solutos: 1. Alumen férrico: $2,5 \mathrm{~g}$ de alumen férrica (cristais de côr violeta clara) dissolver em $100 \mathrm{~cm}^{3}$ de $\mathrm{H}_{2} \mathrm{O}$ (dist.),

2. hematoxilina: $1 \mathrm{~g}$ de hematoxilina em $20 \mathrm{~cm}^{3}$ de álcool a $96 \%$ dissolver e completar com $180 \mathrm{~cm}^{3}$ de $\mathrm{H}_{2} \mathrm{O}$ (dist.). $\mathrm{O}$ soluto adquira sòmente depois de 4 a 5 semanas a sua capacidade de coloração devido da oxidação da hematoxilina em hemateina ao ar livre. Para a coloração usa-se a solução em meia concentração com $\mathrm{H}_{2} 0$ (dist.). A oxidação pode ser apreciada pela adição de $0,2 \mathrm{~g}$ de $\mathrm{NaJO}_{3}$ a $1 \mathrm{~g}$ de hematoxilina. O soluto assim preparado pode ser utilisado imediatamente.

120. Também neste método deve-se preferir freqüentemente a coloração progressiva à regressiva quando são visados quadros gerais ou quando deseja-se a coloração de cortes com diversos órgãos. Para isto emprega-se o soluto fortemente diluído: 1 parte de soluto de coloração em 3 a 5 partes de $\mathrm{H}_{2} \mathrm{O}$ (dist.). O prosseguimento da coloração deve ser controlado de vez enquanto.

121. Hematoxilina férrica segundo WeIGERT.

a) de $\mathrm{H}_{2} \mathrm{O}$ (dist.) os cortes são colocados num banco de coloração numa placa de Petri de forma que se encostam nem em nada e são então cobertos com a mistura de coloração, duração de 1 a 2 minutos,

b) em caso de excesso de coloração diferenciar em ácido clorídrico a $0,1 \%\left(\mathrm{HCl}\right.$ em $\left.\mathrm{H}_{2} \mathrm{O}\right)$, 
Resultado: como em hemalumen mas as côres mais fortes e as estruturas mais finas com coloração mais forte e com separação mais nítida. Depois da hematoxilina segundo Heidenhain êste método é muito apropriado em insetos pois ela representa os diferentes tecidos bem diferenciados. (Indicado principalmente para métodos microanatómicos.)

Solutos: 1. $1 \mathrm{~g}$ de hematoxilina em $100 \mathrm{~cm}^{3}$ de álcool a $96 \%$.

2. $1,16 \mathrm{~g}$ cloreto de ferro em $98 \mathrm{~cm}^{3}$ de $\mathrm{H}_{2} \mathrm{O}$ (dist.) com $1 \mathrm{~cm}^{3} \mathrm{de}$ ácido clorídrico oficinal (ou $4 \mathrm{~cm}^{3}$ de liquor ferri sesquiclorati em 96 $\mathrm{cm}^{3} \mathrm{H}_{2} \mathrm{O}$ (dist.) com $1 \mathrm{~cm}^{3}$ de ácido clorídrico oficinal) . De ambos os solutos são misturadas partes iguais antes do uso. A mistura estrage depois 8 dias, os solutos conservam-se infinitivamente.

Ficou comprovado que em muitos casos um soluto de coloração mais fraco oferece vantagens principalmente na reprodução de estruturas plasmáticas mais finas em células glandulares.

Nêstes casos trabalha-se com 1 parte hematoxilina, com 1 parte de cloreto de ferro e 2 partes de $\mathrm{H}_{2} 0$ (dist.) durante 5 a 6 minutos.

122. Coloração do núcleo com azul de toluidina.

a) de álcool a $70 \%$ para um soluto de alumen férrico de $5 \%$ em álcool a $70 \%$ durante 2 a 3 horas,

b) lavagem em álcool a $70 \%$,

c) colocação em soluto de coloração durante 12 a 24 horas,

d) lavagem em álcool a $70 \%$,

e) álcool a $96 \%$ durante 2 minutos,

f) vermelho de congo ( $1 \%$ em álcool a 96\%), 24 horas (ou 1 hora a $60^{\circ}$ ),

g) álcool a $96 \%$ durante 2 minutos, em seguida álcool absoluto e xilol.

Resultado: coloração do núcleo de azul claro, plasma de coloração fraca, quitina vermelha forte, saliva e secreções também inclusões do plasma das células glandulares coloridos metacromàticamente conforme a sua composição.

Soluto: soluto saturado de azul de toluidina em $\mathrm{H}_{20} \mathrm{O}$ (dist.) misturar depois de 2 dias com a mesma quantidade de álcool de $96 \%$. Para a coloração usa-se dêste soluto-mãe $3 \mathrm{~cm}^{3}$ em $80 \mathrm{~cm}^{3}$ de álcool a $70 \%$. O soluto-mãe conserva-se bem.

Pode-se empregar em vez azul de tolidina também tionina porém esta última ainda é mais sensível a ácidos do que o azul de toulidina.

123. Coloração do núcleo com safranina.

a) de álcool a $70 \%$ para o soluto de coloração, 24 horas,

b) lavagem em álcool a $70 \%$,

c) continuação como em n. ${ }^{\circ} 116 \mathrm{c}$. 
Resultado: Os núcleos brilham de vermelho (basicromatina), melhor como uma coloração contraste com vermelho de congo só e uma com vermelho de congo e verde de luz (fortemente diluido).

Solutos: 1. verde de luz: soluto saturado em $\mathrm{H}_{2} \mathrm{O}$ (dist.), depois de 2 dias completar com o mesmo volume de álcool a $96 \%$, dêste soluto-mãe adiciona-se $3 \mathrm{~cm}^{3}$ a $80 \mathrm{~cm}^{3}$ de um soluto de $1 \%$ de vermelho de congo em álcool a $96 \%$.

2. Safranina: $1 \mathrm{~g}$ de safranina em $70 \mathrm{~cm}^{3}$ de álcool a $100 \%$, adicionar $30 \mathrm{~cm}^{3}$ de $\mathrm{H}_{2} \mathrm{O}$ (dist.).

124. Colorações do núcleo boas, estáveis e simples dão as combinações entre as anilinas de breu sintéticas e de um líquido mordente (detalhes veja BECHER 1921):

125. Galocianina com alumen de cromo:

a) de $\mathrm{H}_{2} \mathrm{O}$ (dist.) para o soluto de coloração durante 24 a 48 horas,

b) $\mathrm{H}_{2} \mathrm{O}$ (dist.) durante 15 a 20 minutos,

c) série dos álcoois, xilol, bálsamo (eventualmente pode ser feito de acôrdo com as necessidades em álcool a $96 \%$ uma coloração de quitina com vermelho de congo, veja n. ${ }^{\circ} 116$ ).

Resultado: sòmente a cromatina dos núcleos tinge-se azul escuro até prêto.

Soluto: Em $100 \mathrm{~cm}^{3}$ do soluto de alumen de cromo a $5 \%$ em $\mathrm{H}_{2} 0$ (dist.) são fervidos exatamente $0,5 \mathrm{~g}$ de galocianina durante $3 \mathrm{minu}$ tos. Depois de esfriar filtrar e completar para $100 \mathrm{~cm}^{3}$ com $\mathrm{H}_{2} 0$ (dis.) O soluto conserva-se diminuindo porém paulatinamente a sua intensidade.

126. Azul de galamina com alumen de potássio execução como com galocịanina em n. ${ }^{\circ} 125$, tingindo porém 12 a 24 horas no soluto de coloração.

Resultado: Núcleos azul brilhantes, limites das células, estruturas fibrilosas, membrana basal e quitina não fortemente incrustada metacromàticamente vermelho atenuado, plasma fracamente azul ou violeta.

Soluto: $\operatorname{Em~} 100 \mathrm{~cm}^{3}$ de soluto de alumen de potássio a $5 \% \mathrm{em}$ $\mathrm{H}_{2} \mathrm{O}$ (dist.) são fervidos $0,1 \mathrm{~g}$ de azul de galamina até a solução, esfriar depois e filtrar. O soluto é estável podendo-se empregar em vez de alumen de potássio alumen de sódio.

127. Alizarincianina $\mathrm{G}$ com cloreto de alumínio: Execução como galocianina em n. ${ }^{\circ} 125$ devendo a duração de coloração ser encontrada empìricamente. A formação da laca de alumínio completa-se de acôrdo com o objeto e a fixação em 1 hora a 24 horas. 
Resultado: Com curta duração tingem-se apenas claramente os núcleos, com duração mais longa também partes do tecido restante. Uma supercoloração não se observa nunca.

Soluto: em $100 \mathrm{~cm}^{3}$ de cloreto de alumínio a $5 \%$ em $\mathrm{H}_{2} \mathrm{O}$ (dist.) são fervidos exatamente $0,25 \mathrm{~g}$ do corante durante 10 minutos, filtrar 2 horas depois e refiltrar uma semana depois. Depois de adição de formol ou timol contra a formação de cogumelos o soluto é estável. Pode ser empregado também em vez de alizarincianina $G$ ou $R R$ naftazarina ou rufigalol.

128. Azul de antrazena com sulfato de alumínio: execução como em galocianina em n. ${ }^{\circ}$ 125, duração de 1 a 3 horas.

Resultado: Núcleos de azul violeta, tecidos em várias tonalidades avermelhados ou violetos.

Soluto: em $100 \mathrm{~cm}$ : de sulfato de alumínio a $5 \%$ em $\mathrm{H}_{2} 0$ (dist.) são fervidos $0,25 \mathrm{~g}$ de azul de antrazena ràpidamente e filtrados 2 ou 3 horas depois. O soluto é estável.

129. Coloração múltipla segundo Gieson .

a) depois da coloração do núcleo com hematoxilina férrica segundo Weigert e lavagem em $\mathrm{H}_{.2} \mathrm{O}$ (corr.) secagem dos cortes com papel de filtro liso,

b) cobrir os cortes com fucsina pícrica durante 1 minuto,

c) retirar o soluto de coloração e secar com papel de filtro liso,

d) álcool a $96 \%$ durante 1 a minutos,

e) álcool a $100 \%$ duas vêzes durante 2 minutos,

f) benzol-xilol-bálsamo de canada.

Resultado: núcleos marrom escuro, tecido vermelho, músculos amarelos. Êste método usa-se sòmente como coloração rápida, pois as côres desabotam depois de algum tempo.

Soluto: fucsina pícrica: $100 \mathrm{~cm}^{3}$ de ácido pícrico aquoso saturado com $1 \mathrm{~cm}^{3}$ de um soluto de fucsina ácida a $1 \% \mathrm{em} \mathrm{H}_{2} 0$ (dist.).

130. A coloração múltipla melhor, mais segura e estável é o método segundo MALlORY modificado por HEIDENHIN (coloração "Azan"). Recomenda-se de evitar objetos com fixadores contendo cromo. 'Todos outros objetos fixados de outra forma podem ser utilizados:

a) de álcool a $96 \%$ para álcool com anilina durante 30 minutos,

b) álcool de $70 \%$ e $40 \%$, cada um durante 2 minutos,

c) $\mathrm{H} .0$ (dist.) durante 3 minutos,

d) colocar em azocarmina a $60^{\prime}$ na estufa durante 15 minutos e em seguida deixar esfriar durante 10 minutos (numa placa com água), 
e) lavagem em $\mathrm{H}_{2} \mathrm{O}$ (dist.),

f) diferenciar em álcool com anilina (com contrôle até que sòmente os núcleos estejam vermelhos). Este processo pode ser apreciado por adição de $\mathrm{H}_{2} \mathrm{O}$ (dist.),

g) álcool com ácido acético durante 1 minuto,

h) soluto de ácido forfortúngstico a $5 \%$ em $\mathrm{H}_{2} 0$ durante 2 horas,

i) $\mathrm{H}_{2} \mathrm{O}$ (dist.) durante 1 hora,

k) azul de anilina-orange-ácido acético durante 3 horas,

1) $\mathrm{H}_{2} \mathrm{O}$ (dist.), série com álcool, diferenciar em álcool a $96 \%$, xilol e bálsamo de canada.

Resultado: Tecido azul, cromatina vermelha, músculos avermelhados até orange, saliva azul, quitina vermelha e amarela conforme a espécie das incrustações.

Solutos: 1. Alcool com anilina: $0,1 \mathrm{~cm}^{3}$ de óleo de anilina pura em $100 \mathrm{~cm}^{3}$ de álcool a 96\%. 2. Azocarmina: 0,1 $\mathrm{g}$ azocarmina G em $100 \mathrm{~cm}^{3} \mathrm{H}_{2} \mathrm{O}$ (dist.) misturar e ferver ràpidamente. Depois do resfriamento filtrar. Os cristais do corrante que depositam-se no filtrado disolvem-se quando aquecidos. A $100 \mathrm{~cm}^{3}$ adiciona-se $1 \mathrm{~cm}^{3}$ de ácido acético glacial. 3. Álcool com ácido acético: $1 \mathrm{~cm}^{3}$ de ácido acético glacial em $100 \mathrm{~cm}^{3}$ de álcool a $96 \%$. 4. Azul de anilina-orange-ácido acético: emprega-se como soluto-mãe $0,5 \mathrm{~g}$ de azul de anilina (solúvel em água) e $2 \mathrm{~g}$ de orange de ouro $\mathrm{G}$ em $100 \mathrm{~cm}^{3} \mathrm{H}_{2} 0$ (dist.) com 8 $\mathrm{cm}^{3}$ de ácido acético glacial. Ferver e filtrar depois do resfriamento. Emprega-se uma parte do soluto-mãe com 3 partes de $\mathrm{H}_{2} 0$ (dist.) .

131. Como coloração de contraste pode-se empregar com resultado satisfatório vermelho de congo isolado (1\% em álcool a $96 \%$, duração da coloração 6 a 10 horas com cortes de 5 micra de grossura, 12 a 24 horas com cortes de 10 micra, 1 a 2 horas quando o soluto de coloração é aquecido a $60^{\circ}$ (veja sob n. ${ }^{\circ} 10$ ).

Resultado: Quitina vermelho brilhante, fibrilas elásticas ligeiramente vermelhas, os outros tecidos tem coloração de diversos graus de acôrdo com o corrante do núcleo.

132. Consegue-se também bons resultados com uma coloração de contraste com vermelho de congo-orange GG:

a) depois da coloração do núcleo com hematoxilina férrica segundo WeIgert ou HeIDENHAIN lavar bem os cortes em $\mathrm{H}_{2} 0$ (corr.),

b) de $\mathrm{H}_{2} \mathrm{O}$ (dist.) para vermelho de congo-orange GG durante 24 horas ou 2 horas a $60^{\circ}$,

c) diferenciar em álcool a $96 \%$,

d) desidratar e incluir em bálsamo de canada. 
Resultado: Núcleos e estruturas fibrilosas como em n..$^{\circ} 119$ e 121 , quitina vermelha ou amarela conforme as incrustações, possibilitando freqüentemente uma separação entre exo - e endocutícula, músculos marrom claro.

Soluto: solutos aquosos e saturados com vermelho de congo e orange GG são misturados em partes iguais (com um pouco de timol contra a formação de cogumelos). Pode acontecer que depois das fixações com misturas de formol ou sublimado os cortes tingem-se só ligeiramente (depende do objeto), nêste caso ajuda freqüentemente uma acidificação ( $1 \%$ de ácido acético glacial no soluto de coloração. Cuidado nos colorações com hemateina) .

133. Para deixar a camada possìvelmente bem fina depois da inclusão dos cortes em bálsamo de canada (importante em caso de imersão oleosa), emprega-se com vantagem bálsamo bem fluído pois depois da evaporação do meio da dissolução a camada torna-se mais fina. Eventualmente deve-se adicionar depois um pouco de bálsamo. Um bom meio auxiliar para a redução da camada de bálsamo é o emprêgo de pequenos pêsos de chumbo colocados na lamínula depois da inclusão. Para pequenas lamínulas de 18 por $18 \mathrm{~mm}$ de comprimento dos cantos bastam pêsos de $11 \mathrm{~mm}$ de comprimento e $5 \mathrm{~mm}$ de diâmetro, para lamínulas de 24 por $32 \mathrm{~mm}$ de comprimento dos cantos tais de $15 \mathrm{~mm}$ de comprimento e $5 \mathrm{~mm}$ de diâmetro, para lamínulas maiores serve na proporção o número maior de pêsos. Bálsamo excedente pode-se tirar depois com uma gilete e lavar com xilol.

134. Na coloração na estufa evita-se de colocar as cuvetas ou vidros abertos na estufa pois as evaporações de água, álcool e benzol ou xilol impurificam a parafina. Melhor é colocar num dessecador ligado com um tubo de borracha para fora. Assim pode-se preaquecer em vidros com rolhos esmeris os líquidos e proceder a coloração.

\section{Temas especiais.}

135. Demonstração da estriação dos músculos: para a prova que a estriação dos músculos não é um produto artifical de coloração são tirados do inseto morto e não fixado fibrilas musculares das partes diferentes do corpo (como exemplos de demonstração recomenda-se o sistema central longitudinal e os músculos da cápsula craniana das lagartas dos lepidópteros). Coloca-se imediatamente:

a) em ácido acético glacial durante 10 minutos,

b) $\mathrm{H}_{20}$ (dist.) durante 10 minutos,

c) $\mathrm{H}_{2} \mathrm{O}$ (dist.) e glicerina $(1: 1)$ durante 10 minutos,

d) glicerina pura, incluir e fechar (veja em n. ${ }^{\circ} 17$ e 18).

Pela absorção d'água tornam-se visíveis as inocómatas no preparado glicerinado das fibrilas isoladas (observação no microscópio de 
contraste de fase, ou na luz polarisada). As listras $\mathrm{Z}$ podem ser reconhecidas. Elas apertam o músculo em forma de segmentos. Esta última observação é especialmente nítida nos músculos com camada forte de sarcoplasma.

136. Para a demonstração da musculatura estriada do esófago ou reto deve ser isolada a musculatura longitudinal e anelar e ser tratada como em n. ${ }^{\circ} 135$. Recomenda-se também uma coloração com hematoxilina de Delafield depois da fixação dos músculos isolados com vapores de formol (veja-se sob n..$^{\circ} 51$ ).

137. Para demonstração da musculatura estriata incompleta do intestino medial (de uma lagarta ou uma larva de um coleóptero) a muscularis é tirada cuidadosamente e tratada como membrana numa plaquinha com ácido acético glacial como em n. ${ }^{\circ} 135$. A membrana é segurada por uma lamínula em glicerina-água 1 : 1 e desdobrada. Em seguida vira-se a lamínula com a pinça e é deitada por cima de uma gota de glicerina na lâmina e fechada. Uma coloração também e possível como em n. ${ }^{\circ} 136$.

138. Para demonstração de partes quitinosas do intestino principalmente dos dentes quitinosos do proventrículo o intestino é preparado e molhado numa plaquinha com um soluto de $1 / 10 \mathrm{n}-\mathrm{NaOH}$. A maceração dos tecidos deve ser controlado. Depois de pouco tempo as partes quitinosas podem ser isoladas por ligeira vibração ou isolação. Vantajoso é uma coloração precedente dos tecidos com vermelho neutro bem diluído.

139. Para uma demonstração colorida dos cromosomos em preparados esmagados das glândulas salivares ou do cérebro das larvas da Drosófila presta-se o seguinte método: colocar o esfregaço durante 2 a 5 minutos no soluto de coloração, em seguida série com álcool e xilol.

Soluto: Aquece-se $60 \mathrm{~cm}^{3}$ de ácido acético glacial adicionando 2 $\mathrm{g}$ de orceina e em seguida $40 \mathrm{~cm}^{3}$ de $\mathrm{H}_{2} \mathrm{O}$ (dist.), filtrando depois do esfriamento.

Em vez dêste soluto pode-se usar também o soluto saturado com carmim em ácido acético glacial a $40 \%$. Êste método nem sempre é seguro, pois as qualidades do carmin estão sujeitas a fortes variações. Apresentação dos cromósomos. Para aumentar cromósomos pela imbibição recomenda-se colocar os cortes antes da coloração num soluto a $2 \%$ de tiosulfato de sódio em $\mathrm{H}_{2} \mathrm{O}$ (dist.). O processo deve ser controlado ou si um contrôle não é praticável por razões técnicas deve-se determinar empiricamente o tempo pois também outras estruturas celulares estão sujeitas a imbibição nêste soluto. Em seguida coloração com hematoxilina ou corrantes específicos de núcleos. 
140. Esfregaço do líquido da cavidade abdominal: Para conseguir líquido da cavidade abdominal morta-se o inseto cortando imeditamente tcdas as 6 pernas no meio do fêmur. Faz-se então pressão uniforme e crescente com uma larga pinça sôbre o abdomen. Assim sai uma grande parte do líquido pelos troncos das pernas. O esfregaço é preparado como com sangue dos mamíferos de forma que a gota na lâmina bem limpa é puxada por um vidro inclinado.

141. Coloração dos esfregaços com hematoxilina férrica — verde de luz segundo HeIdenHain:

a) depois do tratamento com gás de $\mathrm{OsO}_{4}$ ou formol lavar em água corrente,

b) coloração e diferenciação com hematoxilina férrica de Heidenhain (como em n. ${ }^{\circ} 119$ ),

c) de água (corr.) lavar em $\mathrm{H}_{20} 0$ (dist.),

d) continuação como em n. $\left.{ }^{\circ} 142 \mathrm{~h}\right)$ - i).

142. Coloração dos esfregaços com safranina - verde de luz:

a) depois da fixação pelos vapores de ácido ósmico lavar em água (corr.),

b) $\mathrm{H}_{2} \mathrm{O}$ (dist.) duas vêzes, cada vez 10 minutos,

c) álcool a $70 \%$, duração 2 horas,

d) branquear em $\mathrm{H}_{.0} \mathrm{O}_{.}$, duração 10 a 15 minutos,

e) safranina, duração 10 minutos,

f) lavar em $\mathrm{H}_{2} \mathrm{O}$ (dist.),

g) submergir em álcool a $96 \%$,

h) verde de luz $1 / 2-2 / 3$ minuto,

i) álcool a $96 \%$, desidratar e incluir em bálsamo.

Resultado: Cromatina e núcleos vermelhos, plasma e as suas diferenciações verdes.

Solutos: Safranina (solúvel em água) em soluto saturado em $\mathrm{H}_{: 20}$ com óleo de anilina. Verde de luz em soluto de $1 \%$ em álcool a $96 \%$.

143. Coloração dos nervos segundo CoWDRY:

Fixação segundo CARnoy durante 2 a 3 horas,

a) abrir o inseto, preparando eventualmente as partes desejadas,

b) série com álcool até o álcool a 40 'c,

c) lavagem em $\mathrm{H}_{.} 0$ (dist.),

d) soluto de nitrato de prata $1,5 \%$ durante 2 dias,

e) idem, 1 dia,

f) lavagem em $\mathrm{H}_{2} \mathrm{O}$ (dist.),

g) reduzir no escuro durante 24 horas,

h) lavar em $\mathrm{H}_{2} \mathrm{O}$ (dist.),

i) álcool a $96 \%$ durante 1 hora, 
k) álcool de $100 \%$ durante 2 horas,

l) óleo de cedro durante 2 horas,

m) parafina a $60^{\circ}$ durante 3 horas.

(Os objetos devem ser pequenos, insetos inteiros devem ser abertos. De i) - $\mathrm{m}$ ) recomenda-se um vácuo pois fàcilmente ficam restos de água e álcool). O objeto é cortado numa grossura de 2 a 3 micra. Tratamento dos cortes:

a') de $\mathrm{H}_{2} \mathrm{O}$ (dist.) para um soluto de cloreto de ouro $(0,1 \%$ aquoso, neutralisar com carbonato de lítio) durante 2 horas,

b') tiosulfalto de sódio a $5 \%$ durante 5 minutos,

c') água (corr.) durante 6 horas,

d') coloração de contraste em soluto com toluidina (a $1 \%$ aquoso),

e') desidratar e incluir em bálsamo.

Soluto: Líquido de redução: $1 \mathrm{~g}$ de ácido pirogálico, $5 \mathrm{~cm}^{3}$ de formol $(40 \%)$ e $100 \mathrm{~cm}^{3}$ de $\mathrm{H}_{2} 0$ (dist.).

Resultado: Fibrilas nervosas, membrana basal, sarcolema e outras membranas, também tonofibrilas prêtas, células dos nervos cinza-amarelas, substância isotrópica dos músculos auro-amarela, substância anisotrópica, estriações $\mathbf{M}$ e $\mathbf{Z}$ prêtas. Estrutura mais fina da quitina bem nítida, melhor do que com a coloração com vermelho de congo-ácido fosfortúngstico. Devido as tonalidade diferentes de preto e amarelo e a estrutura nítida das fibrilas e membranas o preparado apresenta um quadro plástico.

144. Coloração do cilindro axial segundo MaLlory:

a) fixação em formol a $40 \% 1$ por 3 com água da bica,

b) diretamente num soluto aquoso e saturado de cloreto de chumbo (pouco acima de $1 \%$ ) a $40^{\circ}$ durante 6 dias, mudando o líquido no primeiro, terceiro e no quinto dia,

c) lavar em $\mathrm{H}_{2} \mathrm{O}$ (corr.) durante 24 horas,

d) desidratar e incluir em parafina,

e) cortar com uma grossura de 3 a 5 micra,

f) coloração (soluto veja em baixo) a $60^{\circ}$ durante 30 minutos a 1 hora,

g) 5 a 30 minutos em $\mathrm{H}_{2} \mathrm{O}$ (dist.), acidificar com 2 gotas de ácido acético em $100 \mathrm{~cm}^{3}$ de água,

h) série com álcool até $100 \%$,

i) terpinol,

k) bálsamo de canada dissolvido em terpinol.

Resultado: Cilindro axial azul até preto, núcleo azul, citoplasma azul-cinza, também neutrofibrilas, mas nitidamente separadas. 
Soluto: Soluto I : $1 \mathrm{~g}$ de hematoxilina em $50 \mathrm{~cm}^{3}$ de álcool absoluto, cálcio.

Soluto II: Soluto aquoso saturado de carbonato de magnésia ou

Antes do uso adiciona-se à $20 \mathrm{~cm}^{3}$ do soluto II $1 \mathrm{~cm}^{3}$ do soluto $\mathrm{I}$. A mistura pode ser usado só uma vez.

145. Coloração dos nervos segundo Bubenaite, principalmente para demonstração do aparelho de Golgi:

a) Fixação em formol $(40 \%, 1: 9) 2$ dias ou mais,

b) bicarbonato de potássio (aquoso a 2,5\%) a $34^{\circ}$ durante 2 dias (pendurar os objetos no líquido),

c) secar com papel de filtro,

d) lavar em nitrato de prata a $2 \%$ aquoso a $34^{\circ}$,

e) nitrato de prata a $2 \%$ aquoso a $34^{\circ}$ durante 2 dias,

f) desidratar ràpidamente e incluir, possivelmente com vácuo.

Os cortes com uma grossura de 3 micra são tratados como em 143 a) e b) e a').

146. Cristalisação de secreções.

$\mathrm{Na}$ cavidade de uma lâmina escavada são colocadas escamas frescas, cerdas com secreção ou partes da cutícula ou a própria secreção. A margem da cavidade é fechada com um anel estreito de bálsamo de canada. Em seguida coloca-se uma lamínula de forma que a cavidade é hermèticamente fechada. Leva-se o preparado na estufa com $60^{\circ}$. Aqui evapora uma parte do líquido ràpidamente. Depois de 2 a 3 horas resfriamento eventualmente numa estufa a $40^{\circ}$ até a temperatura do ambiente. Nisto sublima uma parte do líquido evaporado na margem em cristais típicos e conglomerados, que devem ser vistos em luz polarisada. O processo de sublimação pode levar alguns dias. Com uma formação fraca de cristais o processo deve ser repetido e modificado a temperatura e o tempo.

147. Um método vantajoso de ampliar a capacidade e a velocidade de penetração, é o emprêgo de vácuo. O método presta-se não sòmente para a fixação mas também para a desidratação e penetração com parafina. Para isto utilisa-se de uma bomba de jato de água ligada por um tubo fino metálico ou um tubo de borracha grossa por um dessecador normal com uma torneira de três saídas e ligado com um manômetro com mercúrio. Deve ser possível de fechar o manômetro com uma torneira de vidro.

148. Com a ligação da bomba liga-se diretamente o dessecador com a bomba por meio da torneira com 3 saídas e ao mesmo tempo aberta a torneira do manômetro. No caso que a ponta do mercúrio começa abaixar (veja n." 151), existe um vácuo de $380 \mathrm{~mm}$ Hg igual a meia atmosfera. No caso que o mercúrio desce ràpidamente deve-se 
diminuir a pressão da água. No caso da diminuição rápida do vácuo observa-se destruições ou deslocamentos no corpo do inseto que está colocado num recipiente no dessecador. A velocidade mais indicada é 15 a $25 \mathrm{~mm} / \mathrm{Hg}$ por minuto. Nisto escapam do objeto pequenas bolhas de ar. Em pequenos insetos retira-se o ar até quase $350 \mathrm{~mm} / \mathrm{Hg}$, em maiores até quase $250 \mathrm{~mm} / \mathrm{Hg}$, no primeiro caso mais devagar (15 $\mathrm{mm} / \mathrm{Hg}$ por minuto), no último caso mais ràpidamente $(25 \mathrm{~mm} / \mathrm{Hg}$ por minuto). Assim que o vácuo desejado fôr conseguido fecha-se a torneira com 3 saídas desligando a bomba. Em seguida mantendo-se o dessecador com vácuo durante 10 minutos não deixando diminuir a pressão. Fecha-se a torneira no manômetro abrindo a torneira com 3 saídas deixando entrar vagarosamente o ar. Com isto o líquido infiltra-se pelas traquéias para dentro do inseto. A torneira do manômetro deve estar fechada pois a subida do mercúrio pode arrebentar o tubo de vidro. Finalmente abre-se devagar a torneira do manômetro de forma que o mercúrio sobe devagar.

149. Para a pentração com parafina êsse processo é feito dentro da estufa com parafina líquida.

150. Se não existir uma torneira com 3 saídas pode-se empregar também 3 torneiras comuns. Uma torneira fecha o desvio para o manômetro, a segunda fica entre o manômetro e a bomba e a terceira fecha no dessecador um tubo curto pelo qual o ar entra no dessecador. E de vantagem de fechar o tubo quanto mais possível na sua boca, deixando uma abertura mínima de modo que o ar não possa entrar com exagerada velocidade.

151. Manômetro de mercúrio: Como com vácuo maior possam surgir deslocamentos e destruições nos órgãos, deve-se empregar apenas um vácuo entre 380 e $200 \mathrm{~mm} / \mathrm{Hg}$. Forma-se um tubo de vidro da grossura de um lápis e fechado numa extremidade em forma de um $U$ deixando entre os dois braços uma distância de 2 a $3 \mathrm{~cm}$. O comprimento da extremidade fechada é de $40 \mathrm{~cm}$ e da aberta de 35 $\mathrm{cm}$. A ponta do último braço tem uma ligação virada sem comprimento determinado. Monta-se verticalmente numa tábua de madeira ligando na extremidade mais comprida uma medida em $\mathrm{mm}$ solta. Enche-se agora cuidadosamente o tubo de vidro com mercúrio puro não deixando entrar nem água nem ar até que o braço fechado esteja cheio e o menisco do mercúrio na parte aberta vai até 1,5 a $2 \mathrm{~cm}$. A parte de ligação é ligado ao dessecador colocando ainda uma torneira. A medida em $\mathrm{mm}$ é colocada de forma que a marca de $380 \mathrm{~mm}$ está exatamente $380 \mathrm{~mm}$ está $380 \mathrm{~mm}$ por cima do menisco do mercúrio no braço aberto.

152. Se está à disposição borracha natural (latex de borracha = succo engrossado de borracha natural) e a possibilidade de trabalhar com vácuo (quase $300 \mathrm{~mm} / \mathrm{Hg}$, veja n. ${ }^{\circ} 147$ ), pode-se preparar na estufa um soluto saturado em parafina evitando assim o meio de solu- 
ção. Corte-se um pedaço de latex de borracha em pedacinhos mínimos em parafina líquida deixando durante 2 a 3 dias a $60^{\circ}$ remetendo. O soluto corresponde uma mistura de quase $5 \%$ de um soluto de borracha em clorofórmio com parafina. Esta parafina aborrachada é suficiente no emprêgo de vácuo em trabalhos histológicos, sem vácuo o resultado na infiltração é duvidoso. Emprega-se nềste caso melhor o método decrito sob n. ${ }^{\circ} 28$.

153. Meios óticos auxiliares.

Não procure de iniciar o exame de um objeto com um aparelho complicado. Para quadros gerais já bastam aumentos mínimos (possivelmente binoculares), pois pela plasticidade maior a capacidade de imaginação do observador é ajudada. Cada aumento maior diminue a piasticidade.

Em trabalhos morfológicos e anatômicos mais finos como também em trabalhos histolólicos sòmente raras vêzes um meio auxiliar ótico é suficiente. Deve-se recomendar freqüentemente o emprêgo de luz polarisada, dos diversos microscópios com luz transparente e reflectante. Pode ser empregado também aumentos fracos do microscópio eltrônico (como para a estrutura mais fina dos anexos cuticulares). De grande vantagem é na dissolução de estruturas mais finas o microscópio de contraste de fase (p. e. ZEISS-WINKEL) principalmente nos estudos de cortes pela quitina se êstes são ligeiramente coloridos com vermelho de congo ou verde de luz.

Detalhes em literatura técnica especialisada.

154. Ácido clorídrico: $\mathrm{n}-\mathrm{HCl}=3,6 \%$.

Preparo: $10 \mathrm{~cm}^{3} \mathrm{HCl}$ (pêso específico $1,19=23^{\circ} \mathrm{Be} .=37 \%$ ) completar com $\mathrm{H}_{2} \mathrm{O}$ (dist.) até $100 \mathrm{~cm}^{3}$.

155. Ácido clorídrico oficial: adiciona-se ao $100 \mathrm{~cm}^{3} \mathrm{HCl}$ (pêso específico $1,19=23^{\circ} \mathrm{Be} .=37 \%$ ) $50 \mathrm{~cm}^{3} \mathrm{H}_{2} \mathrm{O}$ (dist.) $=$ pêso específico de $1,124=25 \%$.

156. Liquor ferri sesquichlorati $=$ soluto de cloreto de ferro ( $\mathrm{FeCl}_{33}$ ) a $29 \%$ em $\mathrm{H}_{2} \mathrm{O}$ (dist.).

157. Ácido acético glacial = ácido acético concentrado. (dist.).

Ácido acético $=$ soluto de ácido acético glacial a $96 \%$ em $\mathrm{H}_{2} \mathrm{O}$

158. Formol $=$ soluto do gás de formaldehide a quase $40 \%$ em $\mathrm{H}_{2} \mathrm{O}$ (dist.).

159. Álcool = álcool etílico puro, ponto de ebulição do álcool absoluto $=78^{\circ}$.

160. Anilina $=$ Óleo anilina $=$ Aminobenzol.!

161. Água anilinada $=10 \mathrm{~cm}^{3}$ de anilina pura são dissolvidas em $100 \mathrm{~cm}^{3} \mathrm{H}_{2} 0$ (dist.), sacudir. 
162. Pontos de ebulição: acetona $-56^{\circ}$, clorofórmio $-61^{\circ}$, álcool metílico - $67^{\circ}$, álcool etílico - $78^{\circ}$, Benzol $-80,5^{\circ}$, toulol $111^{\circ}$, xilol $-140^{\circ}$, óleo de anilina $-182^{\circ}$, benzoato de metila $-199^{\circ}$, creosot $-205^{\circ}$, terpinol $-210^{\circ}$, óleo de cedro $-237^{\circ}$, óleo de cravo $-247^{\circ}$, glicerina $-290^{\circ}$, óleo de parafina $-300^{\circ}$.

163. Valores de fração $(\mathrm{nD})$ de alguns meios de clarificação e inclusão:

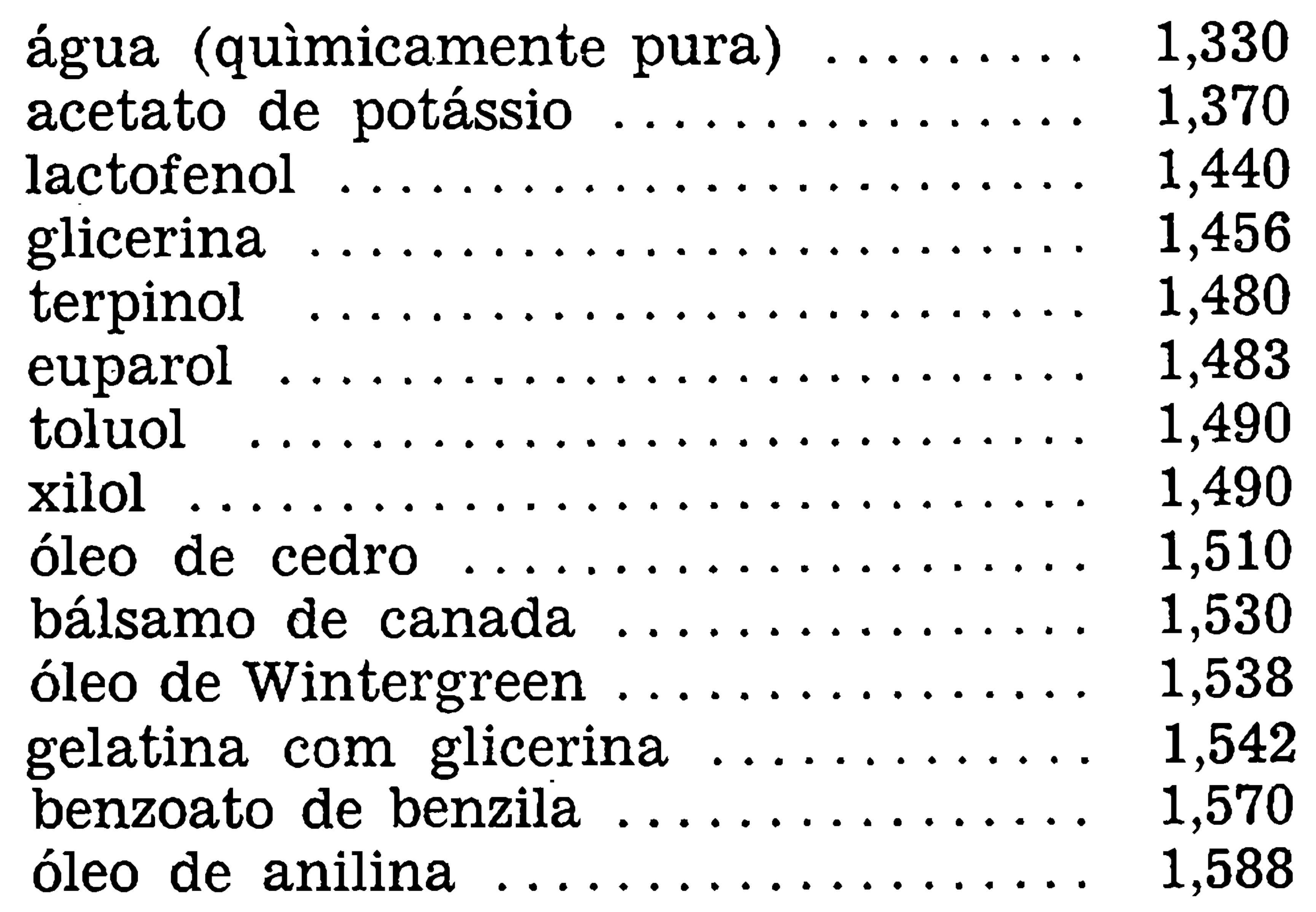

\section{Literatura.}

Indice da literatura veja na parte alemã. Um resumo dos trabalhos mais antigos e mais novos sôbre a microtécnica encontra-se em ROMEIS 1948.

\section{$X$. Indice.}

Acetato de potássio 163

Ácido acético 63, 157

Ácido acético glacial 64, 135, 157

Ácido clorídrico 15, 154, 155

Ácido crômico 49

Ácido fosfortúngstico 130

Ácido ósmico 49, 74

Ácido pirogálico 143

Ácido tricloracético 79

Ácidulação das anilinas 114

Água (pura) 163

Água oxigenada 21

Albumina-glicerina 103

Alcool $51-54,82,83,159$

Álcool com ácido acético 114, 130
Álcool etílico 159

Alumen de crômo 116

Amolecimento da quitina 23

Anexos cuticulares $7,9-12$

Anilinas, ácidas 110

Anilinas, alcalinas 110

Anilinas, anfóteras 110

Anilinas, concentração 111

Anilinas, do breu sintéticas 124

Anilinas, em geral 110

Anilinas, indiferentes 110

Anilinas, neuträs 110

Anilinas:

Alizarincianina $\mathrm{G}$ com cloreto de alumínio 127 
Azocarmina 130

Azul de anilina - orange - ácido acético 130

Azul de antracena com sulfato de alumínio 128

Azul de metilena 15, 31, 32

Azul de toluidina 24, 122, 143

Carmina 116, 139

Carmina com alumen de crômo 116

Galamina com alumen de potássio 126

Galocianina com alumen de crômo 125

Hemalumen ácido 15, 117

Hematoxilina férrica 119, 121

Hematoxilina segundo Delafield 118

Hematoxilina segundo Heidenhain 119

Hematoxilina segundo Weigert 121

Orange 20, 34, 132

Orceina 139

Picrofussina 129

Safranina 123

Sudan III 33

Verde brilhant 31,32

Verde de luz 123, 142

Vermelho de congo 10, 20, 131

Vermelho neutro $15,31,32$

Atonia 3, 4

Bálsamo de canada 163

Benzoato de benzila 24, 163

Benzol 83

Bicromato do potássio 145

Bomba d'água a jato 148

Carbonato de cálcio 144

Carbonato de magnésio 144

Clarificação 19, 24, 25

Cloralhidrato 26

Cloreto de chumbo 144

Cloreto de ferro 121,156

Cloreto de ouro 143

Colamento dos cortes 102

Coloração "Azan" 130

Coloração com anilinas histológicas veja sob anilinas

Coloração dos anexos cuticulares 9 11

Coloração dos músculos 34, 135
Coloração dos nervos $143-145$

Coloração em geral 109

Coloração múltipla 129

Coloração progressiva 112

Coloração regressiva 112

Coloração total $15,29-34$

Corte dos blocos de parafina 99

Cromosomos 139

Depósitos de cromatos 73

Depósitos de formol 73

Depósitos de sublimado 77

Descamação 7

Descorar 21, 70

Desengorar 10

Deshidratação 82

Dessecador 134, 147

Diafanol 23

Diluição de formol 59

Diluição de líquidos 87

Dióxido de cloro com ácido nítrico 23

Dissecção dos insetos $27-29$

Encolhimento 2, 14, 55, 67, 71

Endurecimento dos tecidos 93

Esfregaços 140 - 142

Estendimento dos cortes 105

Estufa 94, 134

Éter acético 2

Euparol 163

Fechamento do preparado 17,18

Fezes dos insetos 8

Fixação com ácido acético glacial 64

Fixação com ácido nítrico 80

Fixação com ácido ósmico 49, 66, 74

Fixação com ácido pícrico 75

Fixação com ácidos pícrico e nítrico 76

Fixação com álcool $51-54$

Fixação com álcool - ácido acético 71

Fixação com bicarbonato de potássio 73,78

Fixação com formol 56

Fixação com gazes 48

Fixação com piridina 81

Fixação com sublimado 55, $77-79$

Fixação com vapores de formaldehide 51

Fixação com vapores de iodo 50

Fixação dupla 37,60

Fixação em geral 33

Fixação, líquidos 38 
Fixaçāo segundo Bouin 75

Fixação segundo Burke 81

Fixação segundo Carnoy 72

Fixação segundo Flemming 74

Fixação segundo Gilson 77

Fixação segundo Heidenhain 78

Fixação segundo Mayer 76

Fixaçāo segundo Orth 73

Fixação segundo Petrunkewitsch 80

Fixação segundo Zenker 78

Formol 56, 662, 158

Gelatina com glicerina 163

Glicerina 13, 14, 163

Grossura dos cortes 99

Hidróxido de potássio 17

Hidróxido de sódio 19

Impregnação 143

Inclusão 89

Indices de refração 163

Injeção do fixador 43,44

Iodo 77

Iodo com iodato de potássio 77

Kava-Kava 3, 4

Lactofenol 163

Líquido abdominal 140

Líquido de conservação segundo Jorres 26

Líquido de conservação segundo Klotz 26

Líquido de redução 143

Maseração 21

Manómetro (de mercurio) 148

Meios auxiliares óticos 153

Meios de inclusão, glicerina 13, 14

Meios de inclusão, xarope de borracha 16

Método de Spalteholz 24

Montagem dos cortes 133, 134

Músculos, estriação $135-137$

Músculos, relaxamento $3-5$
Nitrato de prata 143,145

Observação da superfície 6

Óleo de anilina 25,160,161, 163

óleo de cedro 163

Óleo de cravo 25

óleo de Wintergreen 24, 163

Parafina 83, 89

Parafina com borracha 92, 152

Parafina, diluição 113

Parafina, infiltração 148

Parte quitinosa do intestino 138

Perhidrol 21

Placas de preparação 28

Ponto de ebulição 162

Preparados totais 13,19

Prova de cêra 49

Prova de corpo gorduroso 33

Prova de gordura 49

Prova de músculos 34

Prova de óleo 49

Prova de quitina 20

Relaxamento dos músculos $3-5$

Réplica 6

Sacrificação do inseto 112

Salicilato de metila 24

Secreções, cristalisação 146

Série álcool-benzol 83

Série dos álcoois 86

Soluto de borracha 28

Soluto de celulose 6

Soluto de Ringer 3

Sublimado 55

Terpinol 25, 144, 163

Tetróxido de ósmio 49,74

Tiosulfato de sódio 77

Tiosulfato para cromosomos 139

Toluol 163

Vácuo 147

Xarope de borracha 16

Xilol 163 
XI. Apéndice.

\section{Objetos entomológicos indicados para investigações histológicas.}

\section{rim}

1. estrutura:

a) camadas, lamelas, pseudoporos

b) (ascleritios

2. anexos da cutícula:

a) cabelos falsos

b) cabclos vercladeiros: cerclas, cabelos, escamas

c) cabelos glandulares

d) cabelos sensíveis, covas sensíveis, órgãos coletivos

3. Evaginações da cutícula:

a) espinhões sem ramificarşão

b) espinhoos com ramificação

c) formaçoes monstrosas (atélicas) asas dos tricópteros

lagartas de lepiáópteros (lasiocampídeos, megalopigídeos) adultos dos lepidópteros (arctiideos, noctuideos), culicídeos, lepismatídeos, coleópteros.

lagartas dos arctíldeos, lasiocampídcos: pulvilas dos muscídeos, escamas odoríferas dos machos de lepiriópteros.

partes bocais e antenas de todos os insetos, palpos de lepidópteros, tarsos de muscícleos.

tíbia posterior de lamelicornídeos ou lepidópteros

lagartas de alguns lepiclópteros (Automeris)

Hemípteros: cabeça de fulgoríceos, protorax de membracídeos, pernas de corédeos ou pentatomídeos, corpo inteiro de tingídeos.

4. Hipoderme:

a) estrutura celular

larvas novas com pêle recen-
Método

cortes longitudinais e transversais, veja 1 c)

corte transversal, veja 1 c)

Corte longitudinal. Corrosão com ácido forfortungstico, coloração com vermelho de congo. Luz polarisada ou contraste de fase.

preparado total ou réplica

preparados totais secos em ar ou em bálsamo de canada, cortes transversais

cortes transversais e longitudinais, hematoxilina-vermelho de congo, preparados totais

cortes como em cabelos glandulares, preparados totais dos respectivos órgãos secos ou em bálsamo.

Preparados totais secos em ar, cortes, hematoxilina-vermelho cle congo temente cortes longitudinais e transversais 


\begin{tabular}{|c|c|c|c|}
\hline \multicolumn{2}{|r|}{ Para exame de: } & Objeto & Método \\
\hline & & $\begin{array}{l}\text { mudada, melhor ainda larvas } \\
\text { logo antes da muda }\end{array}$ & $\begin{array}{l}\text { hematoxilina-eosina ou fucsina } \\
\text { ácida, safranina-verde de luz, } \\
\text { coloração "Azan" }\end{array}$ \\
\hline & b) estrutura sincicial & imagines mais antigos & idem \\
\hline & $\begin{array}{l}\text { c) glândulas hipodermais: } \\
\text { glândulas peçonhentas }\end{array}$ & $\begin{array}{l}\text { lagartas de arctiideos, linsio- } \\
\text { campídeos ou megalopigídeos }\end{array}$ & $\begin{array}{l}\text { hematoxilina férrica de Iteide- } \\
\text { nhain, coloração "Azan", azul } \\
\text { de antrazena com sulfato de } \\
\text { alumínio. }\end{array}$ \\
\hline & glândulas odoriferas. . & $\begin{array}{l}\text { fêmeas de ficitíneos (fim do } \\
\text { abdomen), machos de nume- } \\
\text { rosos lepidópteros (p.e. glân- } \\
\text { dules laterais abdominais de } \\
\text { brasolídeos) }\end{array}$ & iden \\
\hline & glândulas hormonais & $\begin{array}{l}\text { lagartas de lepidópteros du- } \\
\text { rante a muda }\end{array}$ & idem \\
\hline & glândulas colagêneas & $\begin{array}{l}\text { pulvilas ou empódio dos arti- } \\
\text { gos tarsais de muitos insetos }\end{array}$ & idem \\
\hline & glândulas de cêra & $\begin{array}{l}\text { abelha de mel, lagartas de } \\
\text { alguns lasiorampideos, hes- } \\
\text { perídeos;Zelus leucograminus }\end{array}$ & idem \\
\hline & $\begin{array}{l}\text { glândulas repugna } \\
\text { tórias }\end{array}$ & $\begin{array}{l}\text { glândulas odorifetas dos he- } \\
\text { terópteros, osmotério das la- } \\
\text { gartas de papilionídeos }\end{array}$ & idem \\
\hline & glândulas mandibulais & $\begin{array}{l}\text { cabeça da abelha de mel ou la- } \\
\text { gartas }\end{array}$ & idem a preparados totais \\
\hline & glândulas labiais & $\begin{array}{l}\text { cabeça respectivamente tôrax } \\
\text { dos heterópteros, das lagar- } \\
\text { tas ou da abclha de mel }\end{array}$ & idem e preparados totais \\
\hline & glândulas do ferrão & $\begin{array}{l}\text { fim do abdomen dos himenó- } \\
\text { pteros aculeatos }\end{array}$ & idem e preparados totais \\
\hline B) & $\begin{array}{l}\text { Músculos: } \\
\text { a) músculos do esqueleto }\end{array}$ & $\begin{array}{l}\text { larvas de muitos insetos (lepi- } \\
\text { dópteros), masculo do tím- } \\
\text { pano das cigarras, fênıur dos } \\
\text { ortópteros, músculos das asas } \\
\text { dos sfingídeos. }\end{array}$ & $\begin{array}{l}\text { hematoxilina férrica de Heiden- } \\
\text { hain }\end{array}$ \\
\hline & b) músculos intestinais: & $\begin{array}{l}\text { proventrículo da barrata, in- } \\
\text { testino medial de larvas fitó- } \\
\text { fagas (lepidópterä). Para o } \\
\text { cxame de fibras finas: intes- } \\
\text { tino medial das larvas parasi- } \\
\text { tárias (icneumonídeos, taqui- } \\
\text { nídeos etc.) }\end{array}$ & idem \\
\hline
\end{tabular}




\begin{tabular}{l|c|c}
\hline Para exame de: & Objeto & Método \\
\hline c) tendões & $\begin{array}{c}\text { pernas dos insetos, bomba sa- } \\
\text { livar dos hemípteros, cabeça } \\
\text { das lagartas dos lepidópteros. }\end{array}$ & $\begin{array}{c}\text { coloração do núcleo com uma } \\
\text { hematoxilina (Weigert) e co- } \\
\text { loração contraste com ver- } \\
\text { melho de congo a 60 }\end{array}$ \\
\hline d) inserções & $\begin{array}{c}\text { cutícula das lagartas dos sfin- } \\
\text { gídeos (inserģóes das grandes } \\
\text { sequências nusculares lon- }\end{array}$ & $\begin{array}{c}\text { hematoxilina férrica de Heiden- } \\
\text { hain ou coloração "Azan" }\end{array}$
\end{tabular}

C) Intestino:

\begin{tabular}{l} 
a) faringe \\
b) esófago \\
(c) proventrículo \\
\hline d) intestino medial \\
\hline e) fim do intestino \\
f) ceco do intestino me- \\
g) tubos de Malpighi \\
h) membrana peritrófica
\end{tabular}

1) Traquéias

a) estigmas

b) sistema das traquéias

(c) rumiticaçaĩo mais fina

(d) traquéolas

e) satcos atreos gídeos (inserções das grandes sequências musculares longitudinais), teto da faringe na cabeça de heterópteros

hematoxilina-vermelho de congo

hemíptera, culicídeos

barrata

idem

iclem

iden

barrata, carabídeo, homóptera

quase todos os insetos

lagartas dos lepielópteros fitíliagos

lizgartas dos lepidópteros

\section{tisanuras}

parede intestinal (somente muscularis) das larvas dos coleópteros, muscídeos ou lepidóptaros

traquedo-branqueas das larvas do 'sygoptera ou ('orychalinar

nos órgãos timpanatis a da esitridulaciano dos ortópteros a homópteros, nas glândulas gonatrópioas dos homópteos cortes longitudinais e transversais, hematoxilina (Delafield) - vermelho de congo-orange (em d) sem coloração contraste, safranina-verde de: luz, azul de antrazena-sulfato de alumínio, coloração "Azan".

hematoxilina-fucsina ácida, corantes de breu

idem e preparados totais

idem

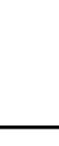

preparados totais ou cortes com hematoxilina-vermelho de congo

clarificação clo preparaclo total membrana inteira vista de cima com hematoxilina ou safranina

sem coloragão com microscópio de rontraste de finse

sem coloração como preparado total, coloraciào total com vermelho de congo, cortes com hematoxilinu-vermelho de (ongo 


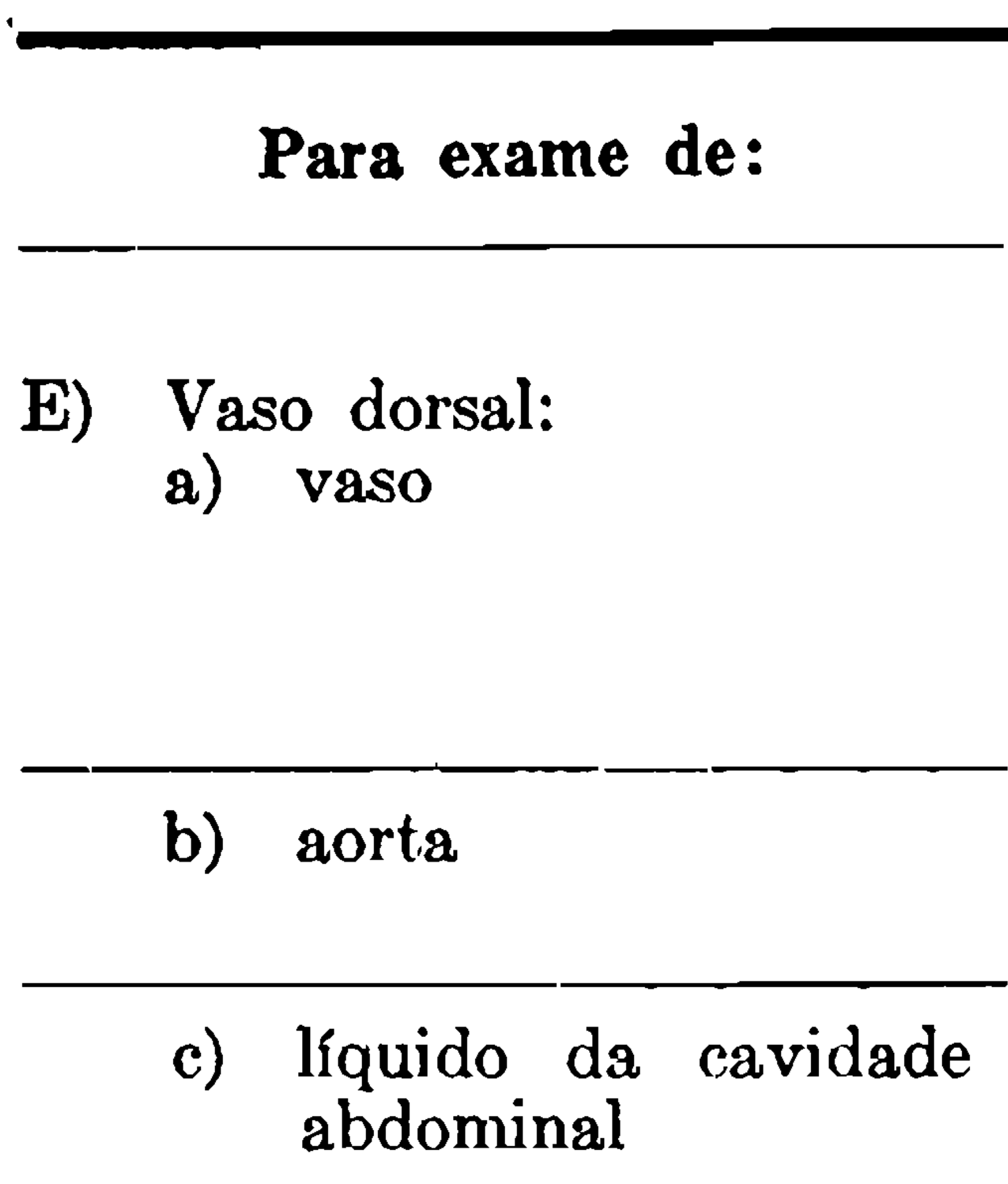

F) Sistema nervoso:

1. aspeto geral

2. ganglios da cabeça lagartas dos sfingídeos (com células pericardiais externas), heteróptera (comı células pericardiais internas!

cabeça (roleóptero ou heteróptero)

principalmente favorável nas lagartas dos sfingídeos

lagartas dos sfingídeos, dípteros grandes (Tabanidae), heteróptera grandes, Vespidae grandes

todos os insetos, principalmente abelha de mel, heteropteros

\section{Método}

hematoxilina férrica de Heidenhain-fucsina ácida

idem

esfregaços, safranina-verde de luz

preparação por corte dorsal, coloração com hematoxilina (Delafield)

série de cortes transversais e longitudinais, hematoxilina férica de Heidenhain (separa com diferenciação forte a camada dos ganglios da das fibrilas), nitrato de prata-cloreto de ouro

preparados totais ou cortes transversais ou longitudinais frontal, hematoxilina férrica de Heidenhain, coloração "Azan", impregnação com prata e ouro

odomatideo

coleópteros (Gyridae)

acrídeos (1. ${ }^{\circ}$ segmento abdominal), tetigonídeos (tíbia anterior)

pedicelos de culicídeos

e) órgão de Johnston

testículos e ovários de acrídeos cigarras etc.

fêmur de heterópteros ou coleópteros, abdomen de odonatas cortes transversais e longitudinais, hematoxilina-vermelho de congo-orange

corte longitudinal, hematoxilina-vermelho de congo ou impregnação com ouro e prata com vermelho de congo

cortes com hematoxilina, principalmente de Heidenhain

cortes transversais com hematoxilina férrica de Heidenhain, coloração "Azan" 


\begin{tabular}{|c|c|c|}
\hline Para exame de: & Objeto & Método \\
\hline I) Corpo gorduroso & lagartas dos lepidópteros & $\begin{array}{l}\text { hematoxilina-fucsina ácida, sa- } \\
\text { franina-verde de luz, esfre- } \\
\text { gaço fixar com ácido ósmico } \\
\text { ou coloração sem fixar com } \\
\text { Sudan III }\end{array}$ \\
\hline $\begin{array}{l}\text { I) núcleos: } \\
\text { a) núcleos ativos }\end{array}$ & $\begin{array}{l}\text { hipoderme das lagartas e lar- } \\
\text { vas durante a muda }\end{array}$ & $\begin{array}{l}\text { hematoxilina férrica de Heide- } \\
\text { nhain, corantes de breu la- } \\
\text { calóides }\end{array}$ \\
\hline b) núcleos degenerados & $\begin{array}{l}\text { hipoderme sincicial de todos } \\
\text { os insetos (alguns dias depois } \\
\text { da muda ou imágines) }\end{array}$ & idem \\
\hline c) macronúcleos & $\begin{array}{l}\text { glândulas labias e mandibu- } \\
\text { lares das lagartas de lepidó- } \\
\text { pteros, da abelha de mel ou } \\
\text { Drosophila, tubos de Mal- } \\
\text { pighi }\end{array}$ & $\begin{array}{l}\text { idem, para cortes, para prepa- } \\
\text { rados totais progressivamente } \\
\text { com hematoxilina (Delafield) }\end{array}$ \\
\hline d) cromosomos & $\begin{array}{l}\text { glândulas gonandotrópicas de } \\
\text { acrídeos, lepidópteros etc., } \\
\text { glândulas labias e cérebro da } \\
\text { larva de Drosophila }\end{array}$ & $\begin{array}{l}\text { cortes e preparados esmargaos } \\
\text { com hematoxilina férrica, or- } \\
\text { ceina, carmina e safranina }\end{array}$ \\
\hline
\end{tabular}

